Pontifícia Universidade Católica do Rio de JaNeiro

\title{
Avaliação da qualidade do serviço de espaços de coworking utilizando o modelo SERVQUAL \\ Sthefany Esposito Alves
}

Trabalho de Conclusão de Curso

Centro de CIÊnCIAS SOCIAIS - CCS

DEPARTAMENTO DE ADMINISTRAÇÃO

Graduação em Administração de Empresas 
Sthefany Esposito Alves

Avaliaçāo da qualidade do serviço de espaços de coworking utilizando o modelo SERVQUAL

Trabalho de Conclusão de Curso

Trabalho de Conclusão de Curso, apresentado ao programa de graduação em Administração da PUC-Rio como requisito parcial para a obtenção do titulo de graduação em Administração.

Orientador(a) : Joāo Renato de Souza Coelho Benazzi 
Epígrafe - "Coworking é onde sua rede social é real" (traduzido de deskmag.com) 


\section{Agradecimentos}

À Deus, por estar sempre comigo e pela oportunidade de me formar em Administração de Empresas, na PUC Rio.

À toda minha família, especialmente meus pais Carlos José de Oliveira Alves e Marcia Esposito de O. Alves, pelo amor, carinho e por que sempre acreditaram em mim, me apoiando e mostrando o lado bom das coisas. Vocês são meus exemplos de vida, ética, trabalho e amor ao próximo!

Aos meus amigos, que acompanharam essa trajetória, desde o colégio até a faculdade. Em especial, aos queridos Monyke Esposito e Diego Menezes, que com seus conselhos e sabedoria, me ajudam a seguir os melhores caminhos.

Ao meu orientador, João Benazzi, por ser tão paciente, didático e se importar com seus alunos, além de ser um brilhante professor. E a professora Veranise Dubeux, por também se disponibilizar a me ajudar nesse trabalho.

Por fim, a todos que colaboraram com esse trabalho, divulgando, opinando, participando. Em especial aos coworkers e à equipe dos espaços Templo, Mères e Nex, por me receberem tão bem, acreditarem no projeto e sempre estarem à disposição para ajudar. 


\section{Resumo}

Alves, Sthefany. Avaliaçāo da qualidade do serviço de espaços de coworking utilizando o modelo Servqual. Rio de Janeiro, 2016. Número de páginas p. Trabalho de Conclusão de Curso - Departamento de Administração. Pontifícia Universidade Católica do Rio de Janeiro.

O presente estudo visa compreender os fatores que influenciam a avaliação da qualidade do serviço de espaços profissionais de coworking na cidade do Rio de Janeiro por seus consumidores, identificando as lacunas que podem existir entre expectativas e o real desempenho do serviço, com uma abordagem específica de marketing de serviços.

Palavras - chave

Coworking; Espaços de trabalho compartilhado; Rio de Janeiro; Marketing; Serviços.

\section{Abstract}

Alves, Sthefany. Coworking Spaces Service Quality Avaliation Using Servqual Model. Rio de Janeiro, 2016. Número de páginas p. Trabalho de Conclusão de Curso - Departamento de Administração. Pontifícia Universidade Católica do Rio de Janeiro.

The present study aims to understand the factors that influence customers perception about the quality of coworking spaces at the city of Rio de Janeiro, identifying the gaps between expectations and service performance, with a specific service marketing approach.

Key-words

Coworking; collaborative workspaces; Rio de Janeiro; Marketing; Services. 


\section{Sumário}

1 O tema e o problema de estudo 1

1.1. Introdução ao tema e ao problema do estudo 1

1.2. Objetivo do estudo $\quad 5$

1.3. Objetivos intermediários do estudo 5

1.4. Delimitação e foco do estudo 6

1.5. Justificativa e relevância do estudo $\quad 7$

2 Revisão de literatura $\quad 8$

2.1. Serviços: conceito e características $\quad 8$

2.2. Qualidade em Serviços 9

2.2.1 Lacunas de falha na qualidade do serviço 10

2.2.2 Mensuraçāo da qualidade em serviços através do Modelo Servqual Error! Bookmark not defined.

3 Métodos e procedimentos de coleta e de análise de dados do estudo 13

3.1. Etapas de coleta de dados 13

3.2. Fontes de informação selecionadas para coleta de dados no estudo

3.3. Procedimentos e instrumentos de coleta de dados utilizados no estudo

3.4. Formas de tratamento e análise dos dados coletados para o estudo

3.5. Limitações do Estudo

4 Apresentação e análise dos resultados 18

4.1. Descrição e análise dos resultados da etapa 1

4.1.1 Templo Gávea: $\quad$ Error! Bookmark not defined.

4.1.2 Mères: $\quad$ Error! Bookmark not defined.

4.1.3 Nex: $\quad$ Error! Bookmark not defined. 
4.2. Descrição do perfil dos entrevistados da etapa 2

4.3. Descrição e análise dos resultados do método 2

4.4. Descrição do perfil dos respondentes do método 3

4.5. Descrição e análise dos resultados do método 3

5 Conclusões e recomendações para novos estudos 43

5.1. Sugestões e recomendações para novos estudos 45

6 Referências Bibliográficas 46

7 Anexo 1

\section{Lista de figuras}

Figura 1: Recorte do mapa que mostra a concentraçāo de espaços de coworking no Brasil (Fonte: http://coworkingmap.org/?s=brazil)Error! Bookmark not defined.

Figura 2: Interesse mundial pelos termos coworking e coworking space (Fonte:http://www.google.com/trends/explore\#q=coworking\%2C\%20coworking\% 20 space $\% 2$ C $\% 20$ espa\%C3\%A7o\%20de\%20coworking\&cmpt=q\&tz=Etc\%2FGM T\%2B3) .0

Figura 3: Mapa dos espaços de coworking no Rio de Janeiro (Fonte:https://www.google.com.br/maps/search/coworking+space+rio+de+janeiro l@-22.9905143,-43.3278797,11z) 0

Figura 4: Censo coworking 2016 (Fonte: https://coworkingbrasil.org/censo/\#download) ..............................................

\section{Lista de Tabelas}


Tabela 1: Diferenças entre as características de Produtos e Serviços (Fonte: Adaptado de Grönroos (1993, p. 38), Bateson \& Hoffman (2016, p.60 76) 0

Tabela 2: Ordem de importância das dimensões da qualidade do serviço de coworking (Fonte: Análise da pesquisa, 2016)..... 0

Tabela 3: Médias das expectativas dos respondentes por atributo (Fonte: Análise da pesquisa, 2016) 0

Tabela 4: Médias das expectativas dos respondentes por dimensão (Fonte: Análise da pesquisa, 2016) 0

Tabela 5: Médias das percepções dos respondentes por atributos (Fonte: Análise da pesquisa, 2016) 0

Tabela 6: Médias das percepções dos respondentes por dimensão (Fonte: Análise da pesquisa, 2016) 0

Tabela 7: Análise dos gaps por atributos (Fonte: Análise da pesquisa, 2016)

Tabela 8: Análise dos gaps por dimensão (Fonte: Análise da pesquisa, 2016) 


\section{O tema e o problema de estudo}

Esse capítulo volta-se à apresentação do tema que se pretende desenvolver e do problema de estudo. Assim, apresenta-se o problema que suscitou a proposta de investigação e respectivos objetivos de pesquisa. Na sequência, são indicadas as suposições e as hipóteses do estudo e se informa a relevância e justificativa do estudo e a delimitação e foco do estudo.

\subsection{Introdução ao tema e ao problema do estudo}

Novas formas de trabalhar surgem a todo momento, fomentando a inovação, a economia de tempo e de dinheiro, a colaboração e o empreendedorismo. Alguns exemplos disso são: trabalho remoto, uso de cafés com wi-fi para trabalhar, homeoffice, coworking, business lounges, horário flexível, coletivos, plataformas online de financiamentos coletivos e troca de serviços, entre outros.

Mas muitas empresas e trabalhadores ainda estão em fase de adaptação a tais novidades, principalmente em países emergentes, como o Brasil. O coworking expressão em inglês comumente utilizada para designar "trabalho compartilhado" particularmente, está tendo uma aceitação muito grande neste país e vê-se um crescimento rápido no número de espaços de escritório que fornecem tal modelo de trabalho nas grandes metrópoles de São Paulo e Rio de Janeiro, principalmente entre 2015 e 2016.

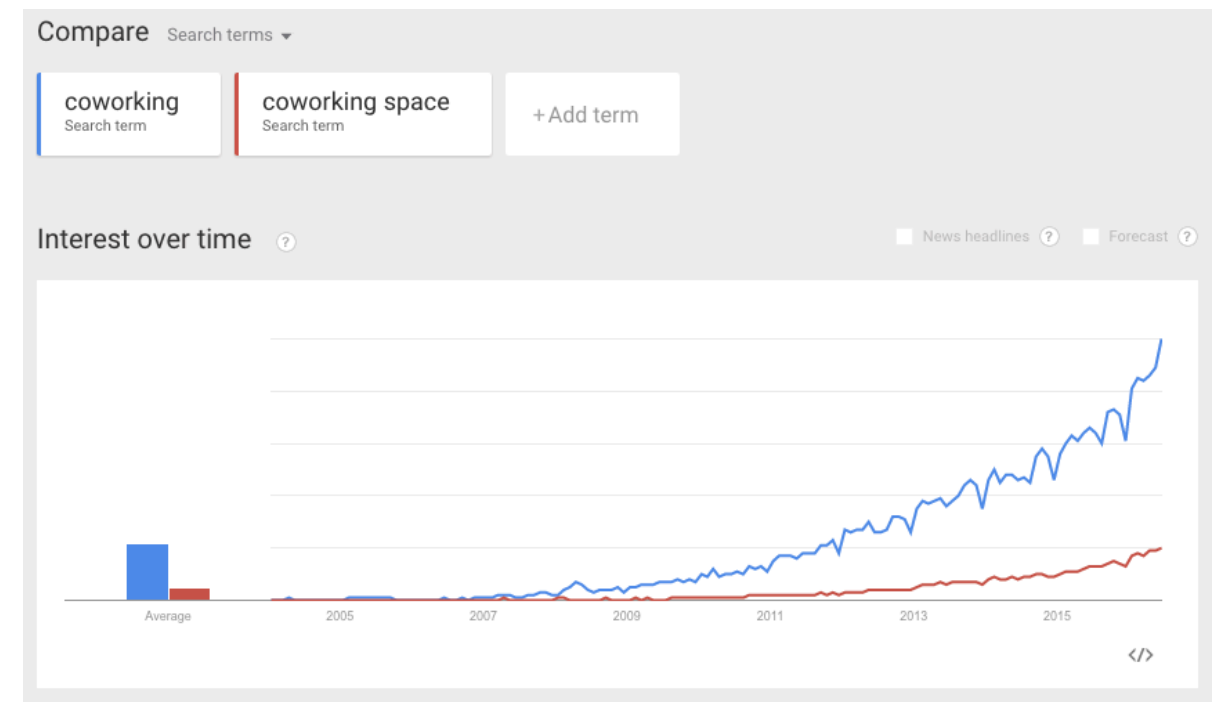

Figura 2: Interesse mundial pelos termos coworking e coworking space (Fonte: Google Trends, 2016) 
No buscador de tendências do Google, os termos coworking e coworking space estão com uma procura crescente entre os anos de 2004 e 2016 . E, quanto ao interesse regional pelo termo coworking, o Brasil ocupa a terceira posição mundial, atrás apenas de Itália e Espanha. (Google Trends, 2016)

Abaixo, temos duas definições que sintetizam a essência do que são espaços de coworking:

"Coworking spaces are defined as work communities where independent entrepreneurs, freelancers, and professionals with workplace flexibility-those self-employed members of the creative class-are able to come together and work side by side, either independently or collaboratively as desired" (Lumley, 2014, p. 40).

"Coworking é uma nova forma de pensar o ambiente de trabalho. Seguindo as tendências do freelancing e das start-ups, os coworkings reúnem diariamente milhares de pessoas a fim de trabalhar em um ambiente inspirador, (..) profissionais independentes que procuram um espaço democrático em que possam desenvolver seus projetos sem $\mathrm{o}$ isolamento do home office ou as distrações de espaços públicos. (...) No coworking, você encontra ambientes especialmente pensados para o trabalho autônomo, muito networking com pessoas de diversas áreas e toda a estrutura para receber seus clientes com um custo menor do que teria ao alugar uma sala comercial. (Site: Coworking Brasil, 2012 Plataforma colaborativa sobre coworking).

Segundo Morisset (2014), o surgimento de espaços de coworking mundialmente deriva de duas tendências interligadas: a emergência de uma economia criativa (Florida, 2002) e a digitalização da economia (Malecki e Moriset, 2008), ambas levando a mudanças profundas no uso dos espaços dedicados ao trabalho criativo. Assim, os chamados trabalhadores criativos são um dos principais públicos-alvo do serviço.

Segundo Florida (2002), o crescimento desse grupo de trabalhadores criativos se deu no surgimento de startups urbanas e de trabalhadores do conhecimento autônomos que, com as tecnologias hoje à disposição, podem trabalhar de qualquer lugar e buscam um terceiro lugar (Oldenburg, 1989) - local que recebe encontros informais, voluntários e frequentes fora dos ambientes de casa e trabalho - para quebrar o isolamento, maximizar a criatividade e o potencial de interação com seus pares. 
O terceiro lugar, pode ser um coffee shop (como os cafés-literários populares na França ou Starbucks Coffee) ou lanchonete, mas há inconvenientes de se trabalhar em um local que não se destina a esse fim - por exemplo: barulho, excesso de movimento, falta de uma estrutura de T.I. apropriada, falta de um local para deixar os equipamentos com segurança, cheiro dos alimentos, olhares curiosos - e fazem muitas pessoas preferirem os espaços profissionais de coworking.

Estes últimos, segundo Morisset (2014), possuem facilidades concebidas para maximizar as interações pessoais entre trabalhadores do conhecimento, sendo caracterizados por uma abundância de espaços abertos, salas de reunião e áreas de relaxamento que visam favorecer a socialização informal entre os trabalhadores/empresas.

Ainda segundo o autor, o sistema de coworking surge a partir desse ambiente de iniciativas colaborativas orientado a profissionais de diferentes instituições e áreas, tendo como objetivo comum o compartilhamento espacial do trabalho. Assim, empresas, coletivos e profissionais liberais podem dividir um mesmo espaço, buscando, entre outros fatores, a redução de custos fixos.

Em um cenário de crise econômica no Brasil, iniciativas de colaboração estão sendo cada vez mais utilizadas, visando não só a economia de recursos, mas também uma maior troca de experiências e sinergias entre pessoas. Nesse contexto, o coworking se apresenta como uma solução interessante para a organização do trabalho, principalmente em grandes cidades como São Paulo e Rio de Janeiro.

Entretanto, na literatura, encontrou-se apenas um estudo acadêmico sobre coworking no Brasil, que trata especificamente do caso de São Paulo (Soares et al., 2015). Devido a essa lacuna e somando-se a expansão do movimento para o Rio de Janeiro, o presente estudo visa entender as percepções dos atuais consumidores de espaços de trabalho compartilhado nesta cidade, adotando uma ótica de qualidade em serviços.

Em relação à estatísticas do movimento no Brasil, o projeto Global Coworking Map (Open Street Map Contributors, 2015) - que trabalha a partir de dados provenientes das próprias empresas de coworking - apurou que em 2015 existiam 191 espaços no Brasil. A maior parte se concentrando em Sāo Paulo, onde começou o movimento no país, com 82 espaços e, em segundo lugar, no Rio de Janeiro, com 47. Contudo, tais dados rapidamente estão se atualizando, devido a tendência de crescimento da atividade.

Observando a figura 4, fica claro que o município do RJ concentra quase todos os espaços de coworking do estado e, que, o centro e a zona sul da cidade do Rio 
de Janeiro são as partes com a maior concentração, seguidos da zona oeste, com destaque para o bairro da Barra da Tijuca, cuja maior parte de moradores sāo de classes A e AA. Isso mostra mais uma característica forte do movimento: a preferência dos coworkers pelas áreas centrais de grandes metrópoles, onde estão o maior contingente de empresas e clientes, com um altíssimo fluxo de executivos.

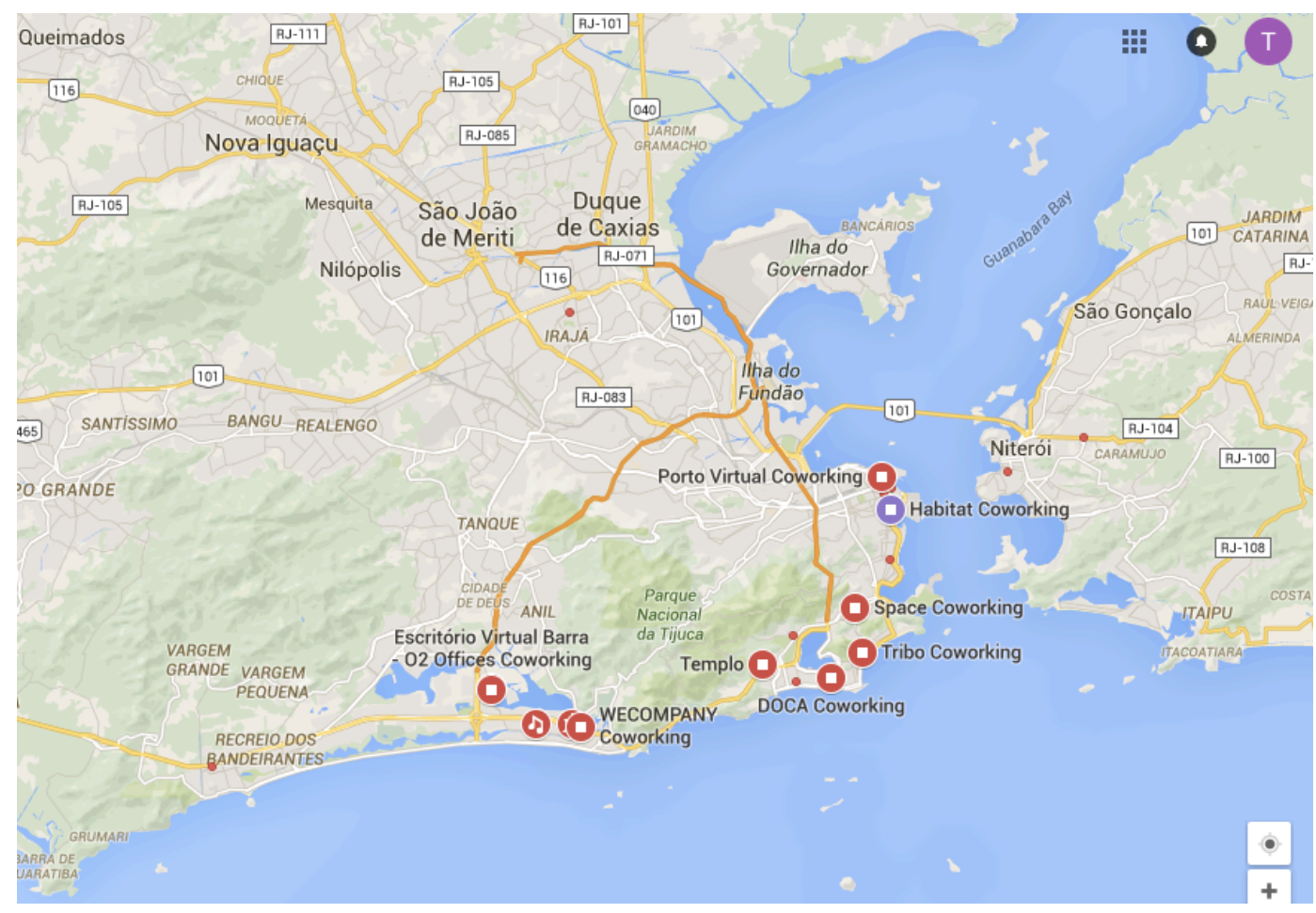

Figura 4: Mapa dos espaços de coworking no Rio de Janeiro (Fonte: Google Maps, 2016)

Em 2016, o projeto Censo Coworking Brasil 2016 - elaborado por funcionários das plataformas Movebla, Ekonomio e Coworking Brasil, com apoio do Seats2meet - realizou o panorama do coworking no Brasil, tendo apurado a existência de 348 espaços ativos no país - um crescimento de 52\% em relação a 2015 - sendo 148 no estado de São Paulo e 35 no Rio de Janeiro, que agora ocupa a terceira posição no ranking nacional. Percebe-se o sudeste como região-piloto do movimento no Brasil.

O Censo apontou que também houve um grande aumento no número de posições de trabalho e que há uma média de 57 coworkers por espaço de coworking. O número de salas de reuniões oferecidas aumentou $147 \%$ em relação a 2015 e, destaca-se um fato curioso: crescimento de 588\% no número de salas privativas. Isso faz supor que, muitas pessoas ainda preferem ter seu espaço privativo à compartilhar um espaço coletivo aberto. Subiu o número de espaços que funcionam $24 \mathrm{~h}$ por dia, mas estes ainda são minoria no país ( $30 \%$ do total); $26 \%$ permitem animais domésticos; 93\% organizam eventos - o que mostra um foco em ações de relacionamento com o cliente e em promoção de networking. 
A pesquisa ainda levantou o perfil dos coworkers, indicando as principais áreas de atuação dos mesmos: consultoria, publicidade, design, marketing, internet, startups, advocacia, negócios sociais, vendas, jornalismo, educação, jurídico, artes, terceiro setor, contabilidade e moda. Assim, percebe-se a coexistência de: profissionais autônomos e empresas, profissões mais tradicionais e outras ligadas à tecnologia e internet.
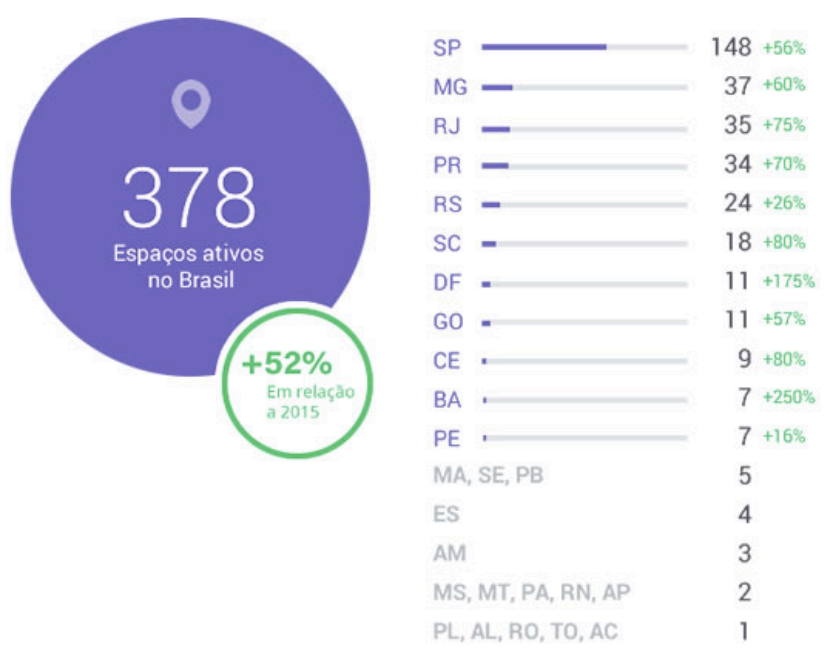

Figura 5: Censo Coworking 2016 (Fonte: Coworking Brasil, 2016).

O cenário é realmente muito favorável para a expansão do movimento coworking em uma cidade como o Rio de Janeiro, mas para que o serviço se desenvolva com qualidade nessa cidade criativa, há de se ter foco no cliente, buscando entender o que está e o que não está agradando os atuais consumidores, para que se produzam espaços alinhados com as necessidades e desejos dos clientes.

Assim sendo, cabe a seguinte pergunta: qual é o nível de qualidade percebido pelo consumidor de serviços de espaços de trabalho compartilhado?

\subsection{Objetivo do estudo}

O objetivo central do estudo é compreender que fatores mais influenciam a qualidade percebida por consumidores de espaços de coworking no Rio de Janeiro, vindo a gerar insights para a concepção de novos espaços e para os existentes.

\subsection{Objetivos intermediários do estudo}

Para se atingir o objetivo final proposto esse estudo prevê, como objetivos intermediários a serem alcançados:

$\checkmark$ Identificar diferenças e semelhanças entre tais espaços, relevantes na avaliação da qualidade do serviço; 
$\checkmark$ Identificar perfil demográfico dos coworkers;

$\checkmark$ Determinar o nível de expectativa dos clientes acerca do serviço de espaços de coworking;

$\checkmark$ Determinar o nível de qualidade percebida pelos clientes desses espaços;

$\checkmark$ Calcular o gap entre expectativas e qualidade percebida.

\subsection{Delimitação e foco do estudo}

Este estudo volta-se mais especificamente para abordar a percepção dos usuários de espaços de coworking no Rio de Janeiro acerca da sua qualidade, através do confronto entre expectativas e realidade, sob o ponto de vista de marketing de serviços. Visa-se analisar o que os consumidores realmente querem obter deste tipo de serviço e se estão se sentindo satisfeitos.

Tal ângulo de análise se mostra interessante por que, como se trata de um tipo de serviço trazido recentemente para o Rio de Janeiro, conhece-se pouco a respeito da maneira do carioca encarar sua dinâmica de funcionamento e, com o aumento de seu fornecimento, poderão ser levados em conta ajustes específicos para esse público.

Embora relevante, não se pretende tratar da questão do home-office como alternativa ao espaço de trabalho tradicional já que tal perspectiva não pressupõe o compartilhamento do ambiente com outros trabalhadores, nem acarreta uma relação mediada por gestores.

Também não será abordado o modelo de escritórios virtuais, que, por vezes, é confundido com a modalidade coworking, mas possui finalidade e estrutura diferentes, sendo destinado a:

“(...) prestar serviços de cessão de salas completamente mobiliadas e decoradas, para uso temporário ou permanente, com infraestrutura completa: central de atendimento e de serviços, incluindo recepção, secretaria, mensageiro, telefonia, internet, equipamentos, manutenção, entre outros, tanto para pessoas físicas como para pessoas jurídicas. " (ANCEV, 2016)

Enquanto o primeiro modelo visa oferecer salas executivas privativas para reuniões, atendimento ou trabalho diário, o segundo cria uma verdadeira comunidade, onde pessoas de empresas e/ou profissões diferentes trabalham lado a lado, compartilhando o mesmo espaço. Porém, já existem espaços híbridos que combinam ambas as modalidades. 


\subsection{Justificativa e relevância do estudo}

As informações que esse estudo pretende produzir podem se mostrar de interesse para:

$\checkmark$ Pessoas em busca de espaços para trabalhar, pois poderão analisar o que devem esperar ao contratar o serviço;

$\checkmark$ Trabalhadores do modelo home-office que nunca utilizaram espaços compartilhados, conhecerem melhor como funcionam esses ambientes, podendo cogitá-los como alternativa;

$\checkmark$ Atuais consumidores de tal serviço, posto que, conseguirão avaliar melhor a qualidade da estrutura que recebem;

$\checkmark$ Gestores dos espaços, que, serão encorajados a analisar os recursos oferecidos, suas práticas atuais e fazer uma auto - crítica. 


\section{Revisão de literatura}

Neste capítulo são apresentados e discutidos aspectos conceituais e estudos relacionados ao tema e estudo em investigação e que servirão de base para a análise realizada.

Esta seção está dividida em 2 partes e abordam, respectivamente, as características de serviços e a qualidade em serviços, para contextualizar o problema de estudo. De início, explana-se sobre características de serviços segundo Gronroos (1993), Hoffman e Bateson (2016). Em seguida, são tratados a qualidade nos serviços, segundo os mesmos autores, e o modelo SERVQUAL de medida da qualidade de serviços, com ênfase no trabalho de Berry, Parasuraman e Zeithaml $(1985,1988)$.

\subsection{Serviços: conceito e características}

"Em geral, bens podem ser definidos como objetos, dispositivos ou coisas, ao passo que serviços são ações, esforços ou desempenhos. [...] A principal diferença entre bens e serviços é a característica da intangibilidade. " (Hoffman \& Bateson, 2016, p.5)

"O serviço é uma atividade ou uma série de atividades de natureza mais ou menos intangível - que normalmente, mas não necessariamente, acontece durante as interações entre cliente e empregados de serviço e/ou recursos físicos ou bens e/ou sistemas do fornecedor de serviços - que é fornecida como solução ao(s) problema(s) do(s) cliente(s). " (Grönroos, 1993, p.36)

Há diversas definições de serviços na literatura, porém, a de Grönroos (1993) abrange os principais pontos citados pelos demais autores, apontando quatro características que são típicas dos serviços, que os diferencia dos produtos físicos: são intangíveis (com diferentes níveis de intangibilidade); são uma atividade ou uma série de atividades; sua produção e consumo acontecem simultaneamente; existe a participação do cliente no processo de produção, pelo menos até certo ponto.

Para as mesmas características, Hoffman e Bateson (2016) utilizaram uma nomenclatura um pouco diferenciada, com termos: intangibilidade, heterogeneidade, perecibilidade, inseparabilidade. 
A Tabela 1, a seguir, mostra as diferenças básicas entre serviços e bens físicos, utilizando as definições dos 3 autores:

Tabela 1: Diferenças entre as características de Produtos e Serviços

\begin{tabular}{|l|l|l|}
\hline \multicolumn{1}{|c|}{ Bens físicos } & \multicolumn{2}{c|}{ Serviços } \\
\hline \multicolumn{1}{|c|}{ Gronroos } & \multicolumn{1}{c|}{ Gronroos } & \multicolumn{1}{c|}{ Hoffman, Bateson } \\
\hline Um produto & Uma atividade ou processo & Ações, esforços ou desempenhos \\
\hline Tangíveis & Intangiveis & Intangibilidade \\
\hline Homogêneos & Heterogêneos & Heterogeneidade \\
\hline Produção e distribuição separadas do con & Produção, distribuição e consumo são processos simu & Perecibilidade \\
\hline Pode ser estocado & Não pode ser estocado & Perecibilidade \\
\hline Pode ser transferido a outra pessoa & Não pode ser transferido a outra pessoa & Perecibilidade \\
\hline Construído em fábricas & Constitui-se em interações entre consumidor e fornee Inseparabilidade \\
\hline Clientes não participam do processo prood Clientes participam do processo produtivo & Inseparabilidade \\
\hline
\end{tabular}

Fonte: Adaptado de Grönroos (1993, p. 38), Bateson \& Hoffman (2016, p.60 - 76).

Apesar de diferentes em vários aspectos, como observado na tabela acima, produtos e serviços são avaliados quanto à qualidade e o aumento no nível desta gera maior atração e retenção de clientes, o que se traduz em vantagem competitiva. Para cada serviço, deve-se levar em conta quais características levarão a desafios críticos de gestão, como os apontados por Hoffman e Bateson (2016), buscando prevê-los e solucioná-los.

O serviço de espaços de coworking pode ser considerado predominantemente tangível, por se tratar de um aluguel de espaço mobiliado, onde evidências físicas são importantes para passar uma imagem de profissionalismo, limpeza, conforto, modernidade - dentre outros - para o cliente e para os clientes do cliente, se tratando de um local onde poderá passar uma grande parte de seu tempo. Vale ressaltar que existem estilos diferentes de servicescape, variando de acordo com o perfil do público desejado e a localização.

A inseparabilidade é uma característica muito forte desse serviço, posto que o cliente, o prestador do serviço (incluindo gestores e funcionários de linha de frente), demais clientes e clientes dos clientes partilham a experiência de serviço, convivendo juntos com maior ou menor frequência, podendo desenvolver laços pessoais e profissionais. Interações são muito importantes e há um grande potencial de networking, um dos atrativos desse tipo de serviço.

Visa-se, com esta pesquisa, entender quais dessas características de serviços constituem fatores críticos na avaliação de qualidade pelos consumidores.

\subsection{Qualidade em Serviços}

Qualidade do serviço é a "atitude formada por uma avaliação global do desempenho de uma empresa no longo prazo" (Hoffman e Bateson, 2016, p.334) e está interligada ao conceito de satisfação do cliente, que seria uma medida de curto prazo específica da operação (Hoffman e Bateson, 2016). Assim, a soma de 
experiências mais ou menos satisfatórias do cliente com o estabelecimento constrói uma avaliação acerca da qualidade.

"Enquanto a satisfação compara as percepções dos clientes com o que eles normalmente esperariam, a qualidade do serviço compara as percepções com o que um cliente deveria esperar de uma empresa que oferece serviços de alta qualidade". (Hoffman e Bateson, 2016, p.334). Assim, a qualidade do serviço parece medir um padrão mais alto de prestação de serviços.

A diferenciação em relação a qualidade do serviço cria uma vantagem competitiva que pode gerar aumento de market share, conquistando novos clientes e também contribuindo para a retenção dos clientes existentes. (Hoffman e Bateson, 2016). Como a empresa prestadora de serviços depende do cliente como um participante no processo de produção, as medidas de controle de qualidade são diferentes das implantadas para bens, onde podem-se eliminar defeitos antes que $o$ consumidor veja o produto. Assim, torna-se mais complexo o desenvolvimento da qualidade para serviços e, deve-se ter atenção diariamente durante a sua gestão e produção. (Hoffman e Bateson, 2016)

Groonros (1993) argumenta que existem três grupos ou protagonistas envolvidos na gestão da qualidade dos serviços: gerência, funcionários e clientes. No presente trabalho, focaremos na ótica do cliente. Esse ator irá basear sua avaliação, a partir do que espera (qualidade esperada) e do que experimenta (qualidade experimentada) nas interações com a empresa. O resultado dessa avaliação será chamado de qualidade total percebida do serviço, existindo quatro resultados possíveis: qualidade inferior, qualidade confirmada, qualidade positivamente confirmada ou qualidade excedente. Uma qualidade aceitável (ou confirmada) será sempre exigida, porém a meta deve ser atingir a qualidade positivamente confirmada, que torna os clientes interessados em continuar o relacionamento com o fornecedor e ainda cria boca-a-boca positivo. A qualidade excedente é considerada boa demais para ser justificável, podendo criar uma percepção distorcida de custo-benefício por parte do cliente.

\subsubsection{Lacunas de falha na qualidade do serviço}

Pensando em compreender melhor como uma empresa pode melhorar sua qualidade global de serviço, Berry, Parasuraman e Zeithaml (1985) desenvolveram a análise dos gaps da qualidade, um modelo que indica a existência de cinco lacunas entre expectativas e percepções por parte de clientes, gerentes e funcionários. Segundo Hoffman e Bateson (2016) e Gronroos (1993), eis a descrição de cada gap: 
A primeira lacuna é a lacuna de conhecimento ou gap na percepção gerencial, que representa a diferença entre o que os clientes esperam do serviço e o que a gerência percebe que eles esperam. A segunda é a lacuna de padrões ou gap na especificação da qualidade, sendo a diferença entre o que a gerência percebe que os clientes esperam e os padrões de qualidade que foram definidos para a prestação do serviço. A terceira é a lacuna de entrega ou gap na entrega dos serviços, a diferença entre os padrões de qualidade previamente estabelecidos para a prestação do serviço e a qualidade real do serviço prestado. A quarta é a lacuna de comunicações ou gap nas comunicações com o mercado, que é a diferença entre a qualidade real do serviço prestado e as promessas feitas pela empresa através da comunicação com o mercado. A quinta é a lacuna do serviço ou gap na qualidade percebida do serviço, que mede a distância entre as expectativas do cliente em relação ao serviço (serviço esperado) e a percepção do que foi realmente entregue (serviço experimentado). É uma função das demais lacunas e, por isso, é a mais importante. A função abaixo contém a definição do gap 5 (Berry, Parasuraman e Zeithaml, 1985):

Gap $5=f($ gap 1, gap 2, gap 3, gap 4) .

Assim, se um gap na qualidade percebida do serviço ocorre, a razão deve ser uma das discutidas anteriormente ou uma combinação delas. "No final, o objetivo da empresa de serviço é fechar a lacuna de serviço ou pelo menos reduzi-la tanto quanto possível " (Hoffman e Bateson, 2016, p. 336), e se esse objetivo não for atingido, pode-se ter como resultado: qualidade confirmada negativamente $\mathrm{e}$ problemas com a qualidade, impacto negativo na imagem corporativa, geração de boca-a-boca negativo, podendo até levar a perda de oportunidades de negócios. Já se for atingido, a qualidade será positivamente confirmada, com a percepção sendo igual ou superior à expectativa, gerando satisfação do cliente. Cabe às empresas buscar atender as expectativas dos consumidores para assegurar a qualidade dos serviços prestados. (Gronroos, 1993; Fitzsimmons e Fitzsimmons, 2004).

Para analisar a qualidade percebida pelos consumidores de espaços de coworking, este trabalho visa a mensuração da qualidade através do cálculo do gap 5 , considerando a diferença entre expectativas e percepções do consumidor.

Um modelo muito utilizado para medir a qualidade em serviços é o Servqual, criado por Berry, Parasuraman e Zeithaml (1988), sendo uma ferramenta que revela pontos fortes e fracos de uma empresa no que se refere à qualidade do serviço. É uma escala de 44 itens que mede expectativas e percepções do consumidor sobre as cinco dimensões da qualidade do serviço, aplicável para empresas de variados ramos. Essas cinco dimensões - tangibilidade, confiabilidade, presteza, segurança e 
empatia - servem como base estrutural da qualidade de serviços. (Hoffman e Bateson, 2016)

Confiabilidade reflete a consistência e a confiabilidade do desempenho da empresa que fornece o serviço. Tangibilidade refere-se a capacidade da empresa gerenciar os elementos tangíveis, como instalações físicas, equipamentos, aparência do pessoal e material de comunicação. Presteza diz respeito aos funcionários serem prestativos e capazes de oferecer pronto atendimento, tendo o compromisso de prestar o serviço no momento correto. Segurança diz respeito a: competência, cortesia com os clientes e segurança das operações da empresa. Empatia é a capacidade da empresa de colocar-se no lugar do cliente, oferecendoIhe atenção cuidadosa e personalizada. (Lovelock e Wright, 2011; Hoffman e Bateson, 2016). Confiabilidade tem sido considerado o fator mais importante e tangibilidade, o menos, na avaliação da qualidade do serviço pelos clientes, segundo Hoffman e Bateson (2016) e testar-se-á se isso se confirma no caso dos espaços de coworking.

A descrição mais detalhada do método será apresentada no próximo capítulo. 


\section{Métodos e procedimentos de coleta e de análise de dados do estudo}

Este capítulo pretende informar sobre as diversas decisões a cerca da forma como este estudo foi realizado.

Está dividido em cinco seções que informam, respectivamente, sobre as etapas de coleta de dados do estudo realizado, sobre as fontes de informação selecionadas para coleta de informações neste estudo. Na sequência, informa-se sobre os processos e instrumentos de coleta de dados realizados em cada etapa, com respectivas justificativas, sobre as formas escolhidas para tratar e analisa os dados coletados e, por fim, sobre as possíveis repercussões que as decisões sobre como realizar o estudo impuseram aos resultados assim obtidos.

\subsection{Etapas de coleta de dados}

Esse estudo visa verificar os níveis de percepção e de expectativa em relação à qualidade dos serviços de espaços de coworking no Rio de Janeiro e medir a diferença percebida entre esses dois fatores (Gap 5).

A primeira etapa de coleta de dados foi exploratória, com abordagem qualitativa, em uma observação participante de espaços de coworking, com objetivo de identificar semelhanças e diferenças gerais entre os mesmos.

A segunda etapa de coleta de dados foi também exploratória, com abordagem igualmente qualitativa, visando gerar insights sobre percepções que podem afetar a avaliação de qualidade. A análise de tais percepções será comparada aos resultados da terceira etapa.

A terceira etapa foi descritiva com abordagem quantitativa. O objetivo dessa etapa foi medir e analisar os níveis apresentados de expectativa e percepção sobre o serviço em relação a diversos atributos, em especial os de qualidade.

\subsection{Fontes de informação selecionadas para coleta de dados no estudo}

A população - alvo é constituída por consumidores dos serviços de coworking no Rio de Janeiro e o fornecimento dos dados foi feito por uma amostra dessa população. A população foi calculada a partir das estimativas obtidas através do Censo Coworking 2016, que apontou a existência de 35 estabelecimentos na cidade 
e do Global Coworking Map, que apontou 47 estabelecimentos, considerando assim uma média de 41 estabelecimentos e multiplicando esse valor pela média de 57 coworkers por estabelecimento (Censo Coworking, 2016). Assim, consideraremos um universo de 2337 pessoas.

O processo de amostragem utilizado nas duas etapas iniciais, foi nãoprobabilístico por acessibilidade e tipicidade. A escolha desse método foi o mais adequado devido a limitação de tempo e custos. A pesquisadora foi conhecer três espaços de coworking no RJ: Templo, Nex. e Mères, situados, respectivamente, nos bairros da Gávea, Glória e Barra da Tijuca. Tais espaços foram escolhidos por terem propostas distintas e serem geograficamente afastados. Houve a oportunidade de entrevistar 9 clientes dos mesmos, que se propuseram a disponibilizar alguns minutos para responder as perguntas. As entrevistas foram feitas individualmente, nas dependências dos espaços.

$\mathrm{Na}$ terceira etapa, o processo de amostragem também foi não-probabilístico por acessibilidade e tipicidade. Um critério pedido foi que os respondentes utilizem ou já tenham utilizado pelo menos uma vez o serviço em questão, no papel de clientes. No caso, a autora pediu para participar de grupos, nas redes sociais Facebook e Linkedin, com a temática do coworking no Rio de Janeiro e, tendo sua entrada aceita, distribuiu o questionário através de postagens. Assim, a pesquisa só foi distribuída nos grupos onde se conseguiu acesso.

Para calcular o tamanho da amostra, utilizou-se a tabela de Arkin e Colton (1976), que determina a amplitude de amostras de populações finitas, com coeficiente de confiança de 95,5\%, na hipótese de $p=0,5$. No caso, trabalhou-se com uma margem de erro de 10\%. Então, foram necessários no mínimo 96 respondentes para a pesquisa. Devido a limitações de tempo, o tamanho final da amostra foi de 56 respondentes, sendo que se obteve esse exato número de questionários válidos, a partir da aplicação de 82 questionários no total.

\subsection{Procedimentos e instrumentos de coleta de dados utilizados no estudo}

Segundo os procedimentos de coleta, a primeira e a segunda etapas foram estudo de campo e a terceira etapa, um levantamento.

Na primeira etapa, os instrumentos utilizados para a coleta dos dados foram: roteiro de observação direta das atividades e fotos tiradas pela pesquisadora nos três espaços de coworking, visando observar características - tangíveis (infraestrutura) e intangíveis (dinâmicas) - dos mesmos que venham a ser comentadas pelos clientes nas etapas posteriores, para obter melhor compreensão. 
$\mathrm{Na}$ segunda etapa, o instrumento utilizado para a coleta dos dados foi entrevistas totalmente estruturadas, visando interrogar alguns consumidores do serviço sobre vantagens e desvantagens que encontram nos espaços. Assim, a pesquisadora primeiro explicou a finalidade do presente trabalho, informou que as respostas são anônimas e, em seguida, perguntou: "O que levou você / sua empresa a buscar espaço de coworking?", "Quais vantagens você percebe em um espaço de coworking”, “E quais desvantagens?”. As perguntas eram abertas, possibilitando total liberdade de resposta.

$\mathrm{Na}$ terceira etapa, o instrumento utilizado foi o questionário e a coleta se deu online, através dos grupos em redes sociais. O questionário em questão foi construído com 23 questões fechadas.

Inicialmente foi realizado um pré-teste com 8 pessoas e, após algumas modificações, validou-se o questionário. Tais indivíduos eram conhecidos da pesquisadora e atendiam aos mesmos critérios da amostra.

O questionário foi elaborado através do software de pesquisa Qualtrics, que gera um link para que se consiga fazer a distribuição via internet. $O$ link foi postado 5 vezes em 15 páginas e grupos do Facebook e outras 3 vezes em 5 grupos do Linkedin, entre os dias 1 e 11 de novembro de 2016, o que resultou em um total de 82 respostas, com 56 válidas.

O questionário continha perguntas fechadas, tanto de resposta única quanto de múltipla-escolha. O método de análise utilizado para as respostas foi análise de frequência. Primeiramente, vinham as perguntas-filtro para validar o respondente. Após essas, foi utilizada escala comparativa por posto ou ordenação forçada, que pedia a ordem de importância entre as 5 dimensões analisadas na escala Servqual desenvolvida por Berry, Parasuraman e Zeithaml (1985). Depois, para a Servqual, foi utilizada a escala Likert, que tem caráter ordinal e cuja análise será feita pela médias das respostas. Finalmente, perguntas sobre dados demográficos, para levantar o perfil do respondente.

Pode-se dizer que o Servqual é um modelo genérico de mensuração da qualidade percebida em serviços, pois se aplica a todos os tipos de serviços. Contudo, em alguns casos é indicado fazer alterações na formulação das sentenças, para se adequar mais especificamente ao tipo de serviço em questão, o que buscouse fazer nesse caso. O modelo Servqual é composto por 44 itens, sendo que 22 deles medem a expectativa dos clientes sobre o serviço e os outros 22, a percepção. Cada questão na expectativa tem uma correspondente na percepção. A diferença entre a expectativa e a percepção gera o gap ou lacuna. Para aferir o grau de expectativa e de percepção em cada item proposto, o respondente atribuiu 
valores para cada item em uma escala de 5 pontos, do tipo Likert, que varia de discordo totalmente a concordo totalmente, correspondendo as notas 1 a 5 , respectivamente, com pesos diferentes. Então, quanto maior a concordância com a questão, maior é o seu peso. Essa concordância com o item define o grau da expectativa e da percepção do respondente sobre o mesmo. Cada valor tem um peso diferente e, para calcular o gap, usa-se da média ponderada dos valores da expectativa, subtraindo os valores da média ponderada da percepção. (BERRY; PARASURAMAN; ZEITHAML, 1985).

No questionário, faz-se análise referente às cinco dimensões que impactam na percepção da qualidade do serviço. Após aplicação dos pré-testes, constatou-se que algumas questões deveriam ser retiradas, devido a terem pouca utilidade prática para essa pesquisa ou serem consideradas repetitivas. Foram retiradas 8 questões, ficando um total de 14, sendo: Confiabilidade: 3 questões; Presteza: 1 questão; Segurança: 3 questões; Empatia: 3 questões; Aspectos tangíveis: 4 questões.

Uma crítica feita ao modelo, seria que no SERVQUAL as dimensões são tratadas como sendo de igual importância. Parasuraman et al. (1994) reconhecem tal problema e propõem uma pergunta adicional na escala SERVQUAL, onde o usuário deve dividir 100 pontos entre as cinco dimensões, demonstrando sua importância relativa. No presente estudo, colocamos a pergunta adicional, a fim de evitar tal problema.

\subsection{Formas de tratamento e análise dos dados coletados para o estudo}

$\mathrm{Na}$ etapa de observação participante, a forma de tratamento e análise dos dados utilizada foi análise das fotos e anotação das características observadas em visita aos espaços.

$\mathrm{Na}$ etapa das entrevistas, a forma de tratamento e análise dos dados utilizada foi a análise de conteúdo.

Já na etapa quantitativa, foi realizado análise de frequência e cálculo de médias. Os cálculos foram realizados com o uso da ferramenta Excel. A base para o estudo do modelo Servqual é o cálculo dos gaps entre expectativa e percepção em relação aos itens do questionário. Os gaps foram calculados pela diferença da média ponderada pela escala, de todos os respondentes em relação à expectativa e à percepção, levando em consideração a escala como fator de ponderação desta média. Cada item teve um gap médio e o gap final é determinado através da média dos gaps por atributo da pesquisa. Para a definição da qualidade, existem três classificações possíveis para o gap: Se a expectativa for maior que percepção, 
qualidade percebida como inaceitável ou abaixo do esperado e gap assume valor positivo; se expectativa for igual a percepção, qualidade é classificada como aceitável e gap assume um valor nulo; se expectativa for menor que percepção, a qualidade é classificada como satisfatória ou mais que satisfatória, e o gap assume um valor negativo (VEIGA; FARIAS, 2004).

\subsection{Limitações do Estudo}

A amostra da pesquisa foi de apenas 56 respondentes e a escolha foi realizada pelo critério de acessibilidade e tipicidade. Isso pode impactar em uma conclusão que não condiz com o comportamento do público em sua totalidade, já que não se realizou uma amostragem aleatória.

Quanto ao levantamento, Gil (1999) destaca as seguintes limitações: ênfase nos aspectos perceptivos (o que a pessoa realmente sente versus o que diz a respeito) e limitada apreensão do processo de mudança. Vale lembrar que ao garantir o anonimato dos respondentes, reduziu-se a primeira limitação e quanto a última, enfatizamos que o presente estudo retrata o momento atual do setor de serviços de coworking (2016).

O uso de questionários também traz algumas limitações, sendo válido destacar que: impede o auxilio ao informante quando o respondente não entende corretamente as instruções ou perguntas e os itens podem ter significados diferentes para cada sujeito pesquisado (Gil, 1999). Porém, aplicando o pré-teste, tentamos diminuir tais chances de falha do modelo. 


\section{Apresentação e análise dos resultados}

Este capítulo, organizado em 3 seções. A primeira apresenta e descreve a etapa de observação participante conduzida em 3 espaços de coworking no RJ. A seguir trata-se da etapa das entrevistas, realizada com 9 usuários de tal serviço. Por fim, a terceira e última seção mostra resultados da etapa quantitativa.

\subsection{Descrição e análise dos resultados da observação participante}

Para a primeira etapa da pesquisa foi feita uma observação participante, que durou em torno de 5 horas em cada espaço de coworking visitado. Propositalmente, os três espaços escolhidos para a observação têm estilos e finalidades distintas: o primeiro é focado no coworking puro, o segundo em escritórios virtuais e salas privativas corporativas, o terceiro é um híbrido dos demais. Além de colher entrevistas com alguns clientes para a $2^{a}$ etapa, também foi conversado com gestores dos espaços, em uma visita guiada com a pesquisadora.

O primeiro espaço visitado foi o Templo, situado em uma casa de $1.200 \mathrm{~m} 2$ na Gávea, onde 2 gestores receberam a pesquisadora, explicando como o espaço funciona e mostrando as dependências. Assim, descrevem a empresa:

"O Templo é uma rede de empreendedores criativos e inovadores. Mais que um coworking, somos uma plataforma de criação e colaboração; pronta para desenvolver o seu negócio e gerar impacto. Acreditamos nas novas formas de organização em rede para construir um novo mundo onde pessoas, ideias e ferramentas estejam conectadas em uma só comunidade."

O público desse espaço, em sua maioria jovem (20 a 35 anos), pertence a várias áreas de atuação, mas há um contingente maior de profissionais de: indústria criativa, economia colaborativa, tecnologia, artes, projetos sociais e profissionais autônomos. A equipe do Templo seleciona através de curadoria os clientes potenciais, para que tenham compatibilidade com o estilo colaborativo do espaço e potencial de parceria com as empresas residentes existentes.

O coworking tem capacidade para até 160 residentes simultaneamente e, hoje, abriga em torno de 30 empresas. Atualmente, $60 \%$ delas utilizam salão compartilhado e $40 \%$ usam sala privativa. O espaço funciona 24 horas por dia, tendo acesso digital para os clientes em aplicativo mobile. 
Os funcionários não se vestem com uniformes nem roupas formais/sociais, são jovens e com estilo despojado, se confundem com os próprios coworkers, gerando aproximação. Eles têm um relacionamento de amizade com os clientes, os quais chamam de residentes, havendo muita troca e interação. Usam palavras com significados profundos para nomear as funções dos funcionários, para enfatizar essa cultura organizacional diferenciada, de aproximação com o cliente. As áreas de atuação em que atuam são: curadoria, comunidade, financeiro, cultura e cuidado. Utilizam muitas redes sociais para se comunicar, como Facebook, Linkedin e outras, além de e-mails.

Quanto aos ambientes, a casa na Gávea é aconchegante e é subdividida em vários espaços, como: jardim (onde acontece o almoço), salões de coworking, salas de reunião e escritórios privativos, além de cozinha compartilhada. No momento da visita, o espaço estava bastante cheio, com muita circulação de pessoas entre os espaços. Com estilo bastante informal, há espaços abertos e fechados, muitas áreas de convivência, um restaurante, salões para eventos, não tem recepção nem recepcionista, o estado de conservação das instalações é bom, a aparência é descolada e criativa (com mensagens nas paredes com giz, arte grafite, instrumentos musicais), não é tão limpo e arrumado quanto os demais espaços visitados, mas é acolhedor, envolvido por natureza. O objetivo é se sentir em "casa", em uma atmosfera informal, sem a sobriedade e frieza características do ambiente corporativo. E, segundo os gestores, o espaço foi desenhado de forma a proporcionar muitos momentos de interação.

Durante o almoço, ouvem-se papos filosóficos e vanguardistas, há intensa construção de amizades e parcerias, as áreas de convivência são movimentadas e nelas pode haver bastante barulho em alguns momentos, como no horário de almoço. A não existência de um recepcionista é mais uma marca dessa informalidade do espaço, que não quer ser confundido com modelo de escritórios virtuais. Eles estabelecem um código de conduta para os residentes, entregue antes de fechar contrato. Um dos desafios, segundo os gestores, é estimular o envolvimento dos residentes na comunidade, pois algumas pessoas não aproveitam o potencial de networking que a casa oferece.

Existem planos de assinatura fixos e flexíveis, de espaço coworking e de salas privativas. Os planos são: desk flex, áreas comuns nas quais se senta onde houver disponibilidade; desk fixo em área compartilhada, a possibilidade de sentar no mesmo espaço todos os dias em um salão compartilhado e trazer um desktop; desk fixo em uma sala compartilhada, no qual duas ou mais empresas dividem uma sala privativa; desk fixo em sala privativa; sala fechada para uma única empresa. 
"Quando as pessoas procuram a gente, a tendência geral é espaços compartilhados pela nossa capacidade de gerir comunidade", disse um dos gestores. Os mensalistas, clientes fixos, são maioria, o que se alinha com esse objetivo de vivência de comunidade.

Em relação aos eventos para a comunidade, existem: reuniões para discutir desafios, ideias e melhorias para a própria comunidade, workshops, palestras, cursos, happy-hours, rede de conexões internacionais, eventos patrocinados, gratuitos ou não, na maioria abertos. Percebe-se que são muito abertos para atividades de integração em geral - por exemplo, realizam um dia "zen" com meditação, um dia com manicure/pedicure - sendo, dos espaços visitados, o que mais as proporciona.

Assim, o nível de interação da comunidade é muito alto. Além de todas as atividades e eventos que acontecem, tem um grupo aberto (público) no Facebook, onde residentes e equipe se comunicam, trocam ideias e divulgam eventos, com interação diária. Percebe-se que o objetivo maior é promover networking, gerir a comunidade. E fazem-se muitas parcerias comerciais lá dentro, entre os residentes.

$\mathrm{Na}$ Mères, o segundo espaço visitado, o diretor explicou como o espaço funciona e mostrou as dependências. Eles estavam em obras no momento da visita, transformando o espaço coworking em auditório.

A Mères fica localizada em uma cobertura que ocupa algumas salas no $\mathrm{O} 2$ Corporate Offices, na Barra da Tijuca, um condomínio sofisticado e moderno com academia, restaurante, portaria, segurança 24 horas, estacionamento rotativo. Todas as salas tem varanda com uma bonita vista para a Barra da tijuca.

Os usuários têm profissões mais tradicionais, como: advogados, empresários, consultores. A maioria usava vestuário social/formal. As idades variam mais que no Templo, com equilíbrio entre pessoas jovens e de meia idade (20 - 55 anos). A maioria dos clientes utiliza salas privativas e a modalidade escritório virtual - sendo esse o plano mais usado de todos - devido ao perfil mais corporativo, representado por advogados, empresários, consultores. Esses profissionais muitas vezes só precisam de um endereço nobre que confira credibilidade para colocar no cartão de visitas e ocasionalmente, utilizam alguma sala para receber clientes especiais.

"Na parte específica para coworking, o cliente fica em média de 6 meses a 1 ano e o seu perfil é o empreendedor ou profissional liberal que está começando, que procura um lugar com custo baixo, mas que quando sua empresa cresce, começa a buscar o espaço individual, com privacidade. Hoje são pouquíssimos usuários do ambiente compartilhado, que será extinto em breve" disse o diretor da empresa, que também falou sobre o barulho, a grande movimentação de pessoas e informações, 
que atrapalha a concentração, como pontos negativos de coworking. Falou que "cada um tem uma educação, um tipo de trabalho, um tom de voz, aí as pessoas tem que botar fone de ouvido para se concentrar. Eu tenho até coworking aqui, mas vou acabar e transformar o espaço em auditório, pois há uma demanda por um espaço assim para cursos, treinamentos, workshops. Para mim, o coworking não vale a pena como negócio. Dá mais certo em locais com aluguel caro, pouca oferta e muita demanda por salas, como, por exemplo, a Zona Sul." Disse também que o formato deles precisa de elegância, de uma cara mais corporativa, sendo confortável. " O nosso cliente principal exige uma apresentação corporativa, com sofisticação."

A equipe é composta por: 1 estagiário para gestão financeira, 1 funcionário de T.I./informática, 1 pessoa que dá suporte a central telefônica, 1 funcionário comercial, 1 recepcionista e 1 faxineira. Todos tem aparência profissional, usam roupa social, além disso, recepcionista e faxineira usam uniformes.

O diretor do espaço tem bastante proximidade com os clientes, está sempre a disposição. A recepcionista faz a gestão dos atendimentos e correspondências. Observou-se que o relacionamento da equipe com clientes, no geral é um pouco mais impessoal e formal que no Templo.

A empresa possui 3 tipos de ambientes e 4 tipos de planos: escritórios virtuais (correspondências profissionais, atendimento presencial e atendimento telefônico personalizado) e fixos, com 3 salas privativas; espaço coworking, que será extinto e transformado em auditório; salas de reunião para 1 a 10 pessoas; auditório para cursos, palestras, eventos ou workshops em distintas formatações. Possui também uma copa, com geladeira e eletrodomésticos diversos. No momento da visita, o espaço estava um pouco vazio.

A Mères foi montada em um conceito corporativo moderno, com instalações modernas, com aspecto de "novo", formais, organizadas, muito limpas, predominando as cores neutras. Não possui lanchonete ou restaurante, mas tem a copa e está localizado em um grande centro empresarial que já possui praças de alimentação. Os espaços são todos fechados, mas todos tem varanda, sendo essa a única área de convivência. Não possuía local específico para eventos, mas agora o auditório serve a essa finalidade.

Quanto aos comportamentos dos clientes, observado durante a visita, não fazem muito barulho durante as interações, o clima é mais formal e tranquilo. Não há tantos momentos e locais para interação entre clientes quanto no Templo, o que condiz com as diferentes finalidades de ambos. 
A Recepção funciona de $9 \mathrm{~h}$ às $18 \mathrm{~h}$ de segunda a sexta, mas o acesso para clientes funciona 24 horas durante os 7 dias da semana. "A enorme maioria usa horário comercial normal, mas tem um ou outro que precisa desse acesso 24/7."

O nível de interação da comunidade é médio a baixo. Realizam alguns eventos abertos e gratuitos para os clientes, geralmente sendo realizados por alguma empresa também cliente, como workshops, palestras. A interação que costuma ocorrer cliente-cliente dura poucos minutos, entre a pessoa chegar, esbarrar em alguém no meio do caminho e entrar na sua sala ou durante algum evento aberto. A maior interação é empresa - cliente: a equipe mantém canal de comunicação através de página no Facebook, mas geralmente a comunicação parte da própria empresa, também possuem blog e comunicações por e-mail e SMS.

O Nex, terceiro espaço visitado, está situado no bairro da Glória, na Villa Aymoré, um luxuoso complexo empresarial, em uma área de $2000 \mathrm{~m} 2$, ocupando 1 prédio inteiro. Localizado a 50 metros do metrô, 5 minutos do aeroporto Santos Dumont e do Centro, área de grande movimento de executivos, que são clientes potenciais. Hoje, conta com 120 clientes e tem capacidade para 300 . O espaço funciona 24 horas, 7 dias por semana.

O Nex, segundo a gestora, está no meio do caminho entre coworking e escritório flexível, agradando a diversos perfis. O público realmente é bem variado, com empresas de várias áreas de atuação, sem predomínio de algum setor. Não fazem curadoria e abrigam empresas de agricultura, engenharia, contabilidade, indústria de eventos, consultoria, tecnologia, entre muitas outras. As "tribos" são bastante variadas, com estilos mais e menos formais, de profissões mais e menos tradicionais. $\mathrm{E}$ as idades também variam, com jovens adultos e pessoas de meia idade, entre 20 - 55 anos.

"Somos uma empresa de conexões e conteúdo. Temos como base espaços de coworking que buscam oferecer não só estrutura, mas criar um ecossistema que inspire outras formas de viver e se relacionar com o mundo por meio de educação, informação e entretenimento. "A gestora citou que existe um movimento de shoppings querendo fazer parcerias com espaços de coworking. Ela também citou como desafios / objetivos: a gestão da comunidade e o cuidado com a experiência de cada coworker na casa, ser uma plataforma que incentiva as conexões e interações da rede.

O local tem recepcionista, com horário de trabalho de $8 \mathrm{~h}$ até as $20 \mathrm{~h}$, mas planejam colocar portaria 24 horas/dia. A equipe da unidade RJ é composta por 6 pessoas, nas seguintes funções: relacionamento comercial, produção de eventos , 2 pessoas na recepção e facilities (cuida da manutenção em geral). Além disso, há 
uma equipe de apoio, que fica no Sul, cuidando da comunicação e do financeiro. E contam com o suporte de uma empresa de inteligência de rede. A faxina é realizada por 3 profissionais terceirizados. A equipe, setorizada, está sempre à disposição dos clientes. Eles avisam aos coworkers sobre comunicados gerais e eventos, através de grupo do facebook, e-mails, SMS. Observou-se que o relacionamento da equipe com clientes é bem próximo e busca se adequar a cada perfil de cliente e situação (mais / menos formal).

O Nex foi o maior entre os espaços visitados, ocupando um prédio inteiro de 3 andares. Entre os visitados, foi o espaço que mais agrada a diferentes perfis de público, devido a variedade de ambientes e planos que oferece: 79 salas privativas para 1 a 10 pessoas, espaços de coworking em 2 andares, salas de reunião de diversos tamanhos, copa, auditório, recepção, espaço fechado para eventos, terraço, áreas de convivência. O local tem estacionamento que funciona $24 \mathrm{~h}$ todos os dias. No momento da visita, o espaço não estava muito cheio, mas deve-se levar em consideração que foi aberto há pouco tempo.

O ambiente é moderno, bastante limpo e organizado, inovador e corporativo com formalidade equilibrada. O prédio é novo, inaugurado em 2016. As áreas de convivência são modernas e aconchegantes, com puffs, sofás, futons e móveis estilosos. No geral, as cores são neutras com alguns móveis coloridos, reforçando o perfil versátil da empresa.

Visando o bem estar no convívio dos clientes, minimizam conflitos em relação a gestão do silêncio, estabelecendo uma regra de não falar no telefone nem se comunicar por videoconferências (exemplo: Skype) na área coletiva. Assim, oferecem pequenas salas específicas para essas ligações, incluídas na mensalidade.

Possui planos de coworking, salas privativas, salas de reunião e auditório, fixos (com contratos de 3 ou 6 meses) e flexíveis (exemplo: diárias, por hora). Segundo a gestora, o " pessoal procura mais estúdio privativo do que área coletiva" para ter opção de ter mais privacidade, ficar em silêncio ou fazer ligações.

O espaço também oferece entretenimento e arte nos corredores, eventos, cafés coletivos, happy-hours e diversos outros momentos de conexão. Toda semana tem palestras, treinamentos e workshops, cursos sobre diversos temas. O nível de interação da comunidade é alto, mas como é um espaço novo, tem potencial de aumentar. A equipe avisa aos coworkers sobre comunicados e eventos principalmente através de grupo fechado no Facebook e e-mails. 


\subsection{Descrição do perfil dos entrevistados}

Dos 9 entrevistados, $33 \%$ pertencem ao sexo feminino e $67 \%$ ao sexo masculino, sendo um público de jovens adultos: a maioria tem idades entre 26 e 35 anos (56\%) e os demais, entre $15-25$ anos (44\%).

A maioria (89\%) pertence a setores criativos e tecnológicos, tendência apontada por Morisset (2014). As empresas em questão possuem entre 3 e 10 funcionários, com uma média de 5 funcionários. $67 \%$ dos entrevistados (6 respondentes) possui ensino superior completo e 33\% (3 respondentes) tem o ensino superior incompleto.

78\% (7 respondentes) são clientes do Templo, na Gávea - Zona Sul, 11\% (1 respondente) do Nex, na Glória - Zona Sul, e 11\% (1 respondente) da Mères, na Barra da Tijuca - Zona Oeste. No Templo, houve maior acessibilidade aos clientes, pois foi possível abordá-los durante momentos oportunos, como horário de almoço.

A maioria dos entrevistados usa o serviço há menos de 6 meses (44\%), alguns entre 6 meses e 1 ano (22\%) e entre 1 ano a 1 ano e meio (22\%) e, a minoria, entre 1 ano e meio a 2 anos (11\%).

Em relação aos ambientes utilizados, a maioria dos respondentes $(89 \%)$ usa áreas de convivência, a maioria (89\%) também usa salas de reunião, $67 \%$ usa salas privativas e $67 \%$ usa espaço com mesas compartilhadas, $56 \%$ usa espaço para eventos e uma minoria de $11 \%$ usa auditório.

\subsection{Descrição e análise dos resultados das entrevistas}

A primeira pergunta que foi feita aos entrevistados questionou os motivos que os levaram a procurar o espaço de coworking. O gráfico abaixo ilustra as categorias de respostas de acordo com a quantidade de vezes que cada categoria foi citada. 


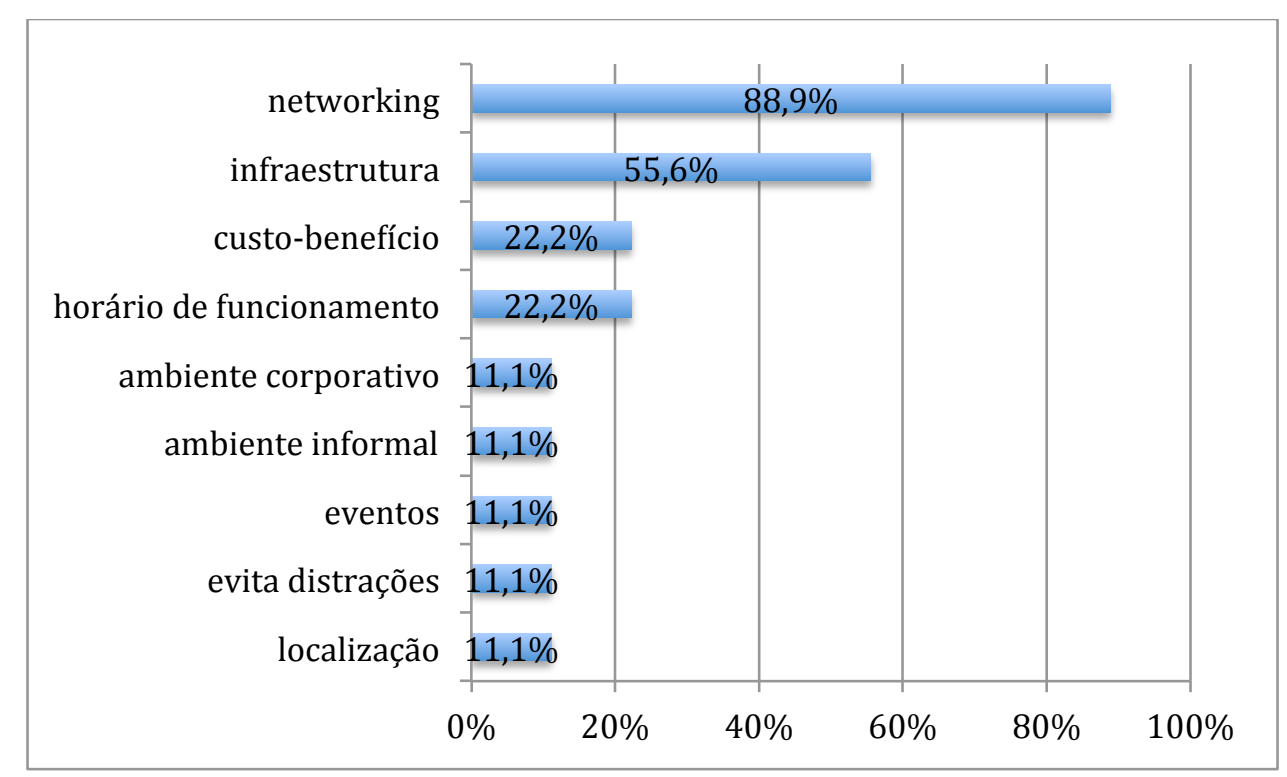

O motivo mais citado foi o networking proporcionado pelos espaços, citado por 8 dos 9 respondentes, que possibilita fazer novas amizades, trocar experiências e conhecimentos, e pode levar a parcerias profissionais/empresariais. Como vê-se na fala do entrevistado: "Aqui conseguimos $n$ contatos, parcerias que não ia ter essa facilidade de conseguir num espacinho fechado, isolado" (3o entrevistado).

O segundo motivo mais citado foi não precisar se preocupar com infraestrutura , que é gerenciada pelos espaços, como: " não ia estar num lugar assim , 2 casas e piano e sei lá, piscina na outra casa (fazendo referencia ao Templo - Botafogo), a estrutura de limpeza" (3o entrevistado), "não preciso me preocupar com infra" (9o entrevistado).

Como terceiros motivos mais citados, houve um empate entre as categorias: custo-benefício e horário de funcionamento.

A relação custo-benefício do coworking deve ser melhor do que se a pessoa alugasse uma sala comercial fora de coworking. Como dito pelo Coworking Brasil (2012), redução de custos é um dos grandes motivos das pessoas procurarem o coworking e, apesar do custo financeiro de trabalhar em casa ser quase zero, há o custo psicológico do isolamento: " [uma sala alugada fora] ia ser uma coisa bem mais simples, mais ou menos pelo mesmo preço." (3o entrevistado), " A empresa onde eu trabalho, está começando e não faz sentido ter um espaço próprio independente. Teria uma custo muito elevado. O coworking funciona como uma alternativa mais barata" (7o entrevistado). Podemos relacionar esta última fala ao que o gestor da Méres comentou na etapa 1, sobre perfil dos usuários de espaços de coworking: " empreendedor ou profissional liberal que está começando, que procura um lugar com custo baixo". 
Quanto ao horário de funcionamento, um dos respondentes frisou a importância de funcionar 24 horas, 7 dias na semana e outro apenas falou da importância do horário de funcionamento: " Hoje em dia ainda mais com a questão de trânsito, você poder fazer uma virada pra fechar um trabalho, é essencial. Aqui funciona 24 horas, mas não pode dormir, pode virar noite trabalhando. " (4o entrevistado). Como observado no capítulo 1, no Brasil, subiu o número de espaços que ficam abertos 24 horas todos os dias, porém ainda são minoria. Vale lembrar que todos os entrevistados usam espaços que funcionam 24 horas nos 7 dias da semana, mas uma análise quantitativa da procura dos clientes cariocas por esse horário integral será feita na próxima etapa, do questionário.

O ambiente ser visivelmente corporativo, mais formal, é importante para alguns usuários, que precisam passar seriedade e credibilidade a seus clientes: "O que eu acho muito bom é que lá é claramente um ambiente corporativo, não é que nem o Templo mais informal " ( 60 entrevistado - cliente da Mères). Por outro lado, um ambiente informal é preferível para outros usuários, agradando a um outro perfil de profissional: "por ser um ambiente menos formal" (10 entrevistado).

Poder participar de eventos da comunidade, que são ações de relacionamento, também é um motivo para a escolha de espaços de coworking: "estar engajado em eventos" (2o entrevistado). Como visto no capítulo 1, este é um grande diferencial do serviço.

Alguns consumidores acham que estar em um ambiente com outros profissionais ajuda a se concentrar, evitando as distrações que teria em espaços públicos e em casa, como vê-se na seguinte fala: " Meu problema com minha casa, tem muitas coisas na minha mesa, coisas que contribuem com o trabalho de certa forma, mas também distraem, e também tem cama, se eu estiver querendo focar, é melhor que só tenha um laptop na minha frente." (4o entrevistado)

A localização do espaço também é um motivo importante e pode ser vista tanto do ponto de ser próximo a casa do coworker - como na seguinte fala: " estar perto da casa de todo mundo é bom. Aqui é perto para todos os sócios, eu sou o que moro mais perto, venho a pé" (5o entrevistado) - quanto de ser perto para seus clientes, próximo a locais com grande fluxo de executivos.

A segunda pergunta foi um questionamento dos pontos positivos ou vantagens que o entrevistado vê em espaços de coworking. Todos os itens citados nas respostas da pergunta anterior foram novamente citados, exceto "ambiente corporativo" e adicionou-se menções a: ambiente, equipe, colaboração e flexibilidade contratual. 


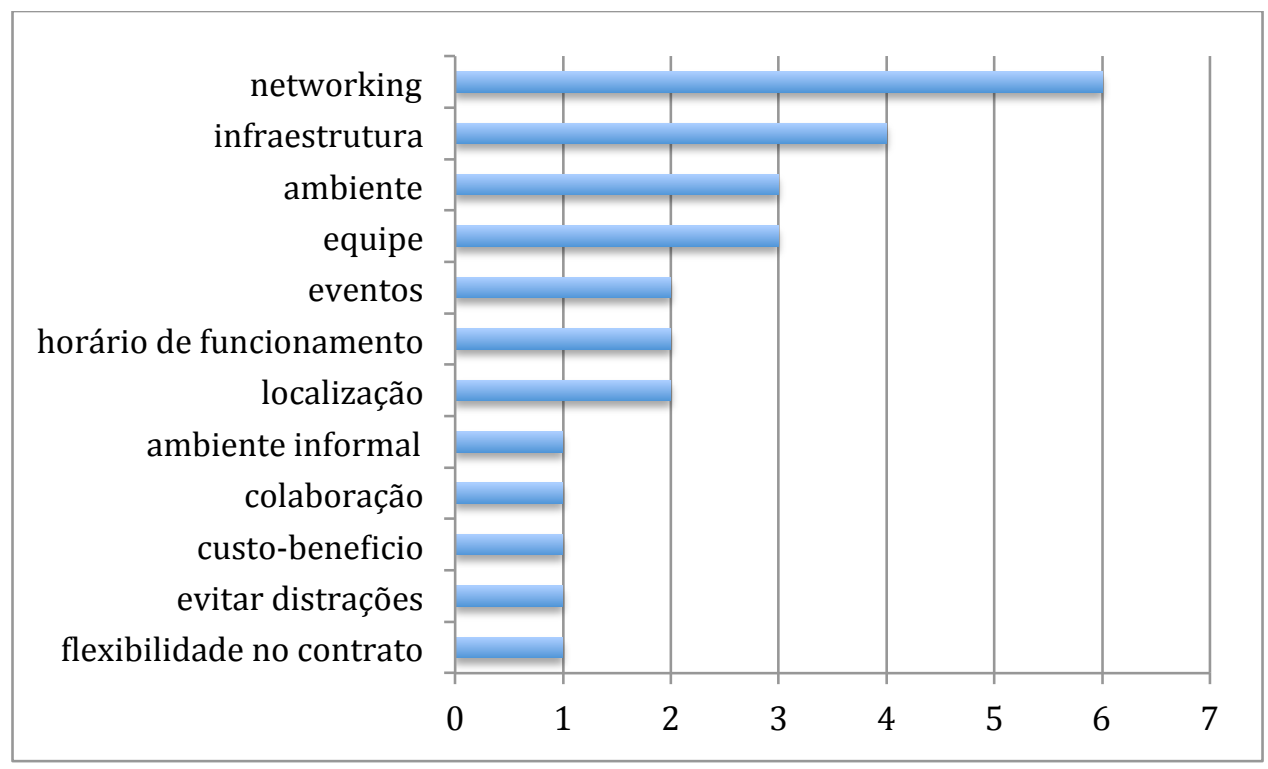

Mais uma vez o motivo mais citado foi o networking proporcionado pelos espaços, citado por 6 dos 9 respondentes (67\%), como vê-se na fala de um entrevistado: "interação entre os residentes, rotatividade de empresas e estímulo de novas parcerias" (8o entrevistado).

Novamente o segundo motivo mais citado foi a infraestrutura oferecida, citada por 4 dos 9 respondentes (44\%), como dito em: "Praticidade de não precisar se preocupar com contratação de internet, ligar o gás, ligar a luz, enfim, pagar contas mensais. A gente só paga uma conta e vem tudo no mesmo pacote." (10 entrevistado).

Como terceiros motivos mais citados, ambiente e equipe, citados por 3 dos 9 (33\%) respondentes. Quanto ao ambiente, que se relaciona com a dimensão da tangibilidade (Hoffman e Bateson, 2016), falou-se sobre a atmosfera do lugar e destacou-se instalações serem modernas: "o ambiente em si, eu gosto muito dessa casa aqui, da vibe, ter um lugar aberto pra trabalhar," (5o entrevistado), lugar agradável e moderno" (9o entrevistado). E sobre a equipe, falou-se positivamente com entusiasmo, destacando a dimensão presteza (Hoffman e Bateson, 2016): "sempre tem alguém ai, fazendo o cuidado da casa, galera muito boa " (5o entrevistado), "o diretor de lá é super amigável, prestativo, então ele tá sempre querendo ajudar" (6o entrevistado).

Como 40 motivo mais citado, houve empate entre: eventos, horário de funcionamento e localização ( $22 \%$ cada). E os demais motivos citados, com $11 \%$ da respostas cada, foram: ambiente informal, colaboração, custo-benefício, evitar distrações e quebrar o isolamento, flexibilidade contratual. 
A terceira e última pergunta, questionava sobre desvantagens que 0 entrevistado vê em espaços de coworking. Dos 9 respondentes, um não soube opinar e outro mostrou certa dificuldade em opinar, o que leva a duas hipóteses: ou estão totalmente satisfeitos com o serviço ou desconfiaram dos objetivos da pesquisadora pelo fato da entrevista ter sido conduzida dentro dos espaços de coworking. Além disso, 4 respondentes demonstraram tranquilidade em relação às desvantagens, não as considerando graves.

As desvantagens citadas foram variadas, não houve homogeneidade nas respostas, cada uma tendo sido citada apenas 1 vez, exceto por uma que fora citada 2 vezes. Os pontos negativos apresentados foram: falta de privacidade, regras, problemas na infraestrutura, gestão do silêncio, localização, custo-benefício, erros no registro de recados, área de convivência pequena, distrações, disputa por salas de reunião, poucos eventos com objetivo profissional, falta engajamento da comunidade. Um fato curioso foi que alguns pontos que foram considerados como vantagem anteriormente, agora são citados como desvantagem: infraestrutura, localização, custo-benefício, distrações, eventos.

A única desvantagem citada mais de uma vez foi falta de engajamento da comunidade, dita por 2 dos 9 respondentes, como se vê nas falas: "ambiente com alta dispersão, cada empresa está no seu ritmo e não estão alinhados com um mesmo objetivo " (8o entrevistado) e " criar uma rotina de divulgação e motivação pra galera se engajar mais. Porque se deixar a própria comunidade criar esses movimentos de forma orgânica, nada acontece ou acontece num engajamento bem low. " (9o entrevistado). Percebe-se então que ainda há uma dificuldade dos espaços em gerir o engajamento de suas comunidades, as trocas de experiências e sinergias entre pessoas - networking (capítulo 1), por mais que esse seja o objetivo mais divulgado de muitos deles. Lembrando que a gestora do Nex citou que incentivar as conexões e interações da rede é um grande desafio.

Quanto a falta de privacidade, foi falado: " tem situações que podem causar incômodo para algumas pessoas, mas não pra gente, a gente tem uma sala, mas o que pode incomodar algumas pessoas é essa falta de privacidade o tempo todo." (10 entrevistado).

Quanto a regras, mencionaram: "o espaço não ser totalmente nosso, se a gente quiser fazer um evento que seja lucrativo, a gente tem que pedir autorização.[...] Poderia ser um problema, mas você entendendo como a comunidade funciona, você entende e aceita. " (2o entrevistado). No espaço de coworking que tal entrevistado usa, os gestores fornecem um manual de 
convivência, com essas e outras regras, antes mesmo do contrato ser firmado, então, os consumidores estão cientes das mesmas.

Os problemas na infraestrutura citados foram : "defeitos, basicamente, coisas estruturais, as vezes internet, ou uma obra." (3o entrevistado).

Quanto a localização, falou-se sobre o fato de não ser próximo da casa do coworker: "É um pouco longe pra mim, não muito, mas um pouco longe." (6o entrevistado).

Quanto ao custo-benefício, foi falado do preço do plano de sala privativa: "Eu acho o aluguel da sala privativa caro, que você faz um pacote de horas e quando ultrapassa esse pacote, você paga a hora" (6o entrevistado). No capítulo 1, falou-se que a redução de custos fixos é um motivo da escolha por espaços de coworking. E, por mais que uma sala privativa tenha custo mais elevado, o custo-benefício deve ser melhor que o se a empresa alugasse uma sala comercial e montasse a estrutura.

Quanto à distrações, no capítulo 1 e em resposta a pergunta anterior, foi citado que o coworking evita distrações que o profissional teria em casa ou em espaços públicos e agora, mostra-se o outro lado, que se a pessoa não for disciplinada, as constantes oportunidades de interação podem atrapalhar a se concentrar: "muitas empresas ficam muito à vontade e acabam não sendo muito produtivas". (8o entrevistado). Lembrando que essa desvantagem do espaço compartilhado foi citada pelo gestor da Mères, na etapa anterior.

Em relação a eventos, a desvantagem citada foi a falta de eventos com objetivo profissional para trocas de conhecimento: "Eu sinto falta de mais eventos internos de compartilhamento de conhecimento: mini talks e workshops. A frequência de festinhas está boa. 1 vez por mês tem algum happy-hour maneiro, mas poderia ter algum hunter pra gerir mais mini talks." (9o entrevistado). No capítulo 1, foi falado sobre a importância do foco em ações de promoção de networking. Acredita-se que temáticas profissionais são realmente importantes para os eventos.

Quanto à gestão do silêncio, comentou-se: " uma vez ou outra o barulho, mas o pessoal costuma respeitar bem, as vezes falam um pouquinho mais alto." (5o entrevistado). Tal desvantagem também foi anteriormente comentada pelo gestor da Mères.

Também foi falado que ocorrem alguns erros no registro de recados, por parte da recepção: Às vezes, a secretária escreve nome errado, ou e-mail errado ou telefone errado, pra nossos clientes, deveriam ser mais atentos em relação a isso." ( 60 entrevistado). Isso fere a dimensão da confiabilidade (Hoffman e Bateson, 2016). 
Um dos entrevistados citou como desvantagem a área de convivência ser pequena: "às vezes o espaço de convivência é pequeno e não é suficiente para todos" (7o entrevistado). No capítulo 1 , falou-se que uma característica muito comum em espaços de coworking é a abundância de espaços abertos e áreas de relaxamento para socialização informal. Entende-se que esses ambientes são importantes em tais espaços, principalmente nos que focam em proporcionar networking com muita interação.

Outro citou a disputa por horário na sala de reunião: "disputa pela sala de reunião" (8o entrevistado). Deve-se levar em consideração que o espaço que ele utiliza não possui recepção nem secretárias, os próprios coworkers se organizam na gestão desses horários. Como citado no capítulo 1, o número de salas de reuniões oferecidas mais que dobrou em relação a 2015. Assim, sugere-se oferecer mais salas de reunião para os coworkers desse espaço (Templo), que foi o mais populoso entre os visitados e tem apenas 1 sala de reunião à disposição.

\subsection{Descrição do perfil dos respondentes do questionário}

Nesta etapa, foi feita uma análise descritiva dos respondentes do questionário. Devido à limitação de tempo foram obtidos apenas 82 questionários com 56 válidas $(n)$, que passaram na pergunta-filtro.

A maior parte dos respondentes válidos do questionário são jovens adultos, com idade entre 15 a 25 anos $(31,7 \%)$ e 26 a 35 anos (29,3\%), com estimativa pontual da média sendo 32 anos. Houve um equilíbrio entre respondentes do sexo masculino $(52,4 \%)$ e feminino $(47,6 \%)$.

Quanto a suas áreas de atuação, a maioria trabalha em startups (33,3\%), consultoria $(28,6 \%)$ e marketing $(23,8 \%)$. As demais estão ilustradas no gráfico abaixo. Esse perfil vai de encontro às principais áreas de atuação apontadas pelo Censo Coworking Brasil 2016.

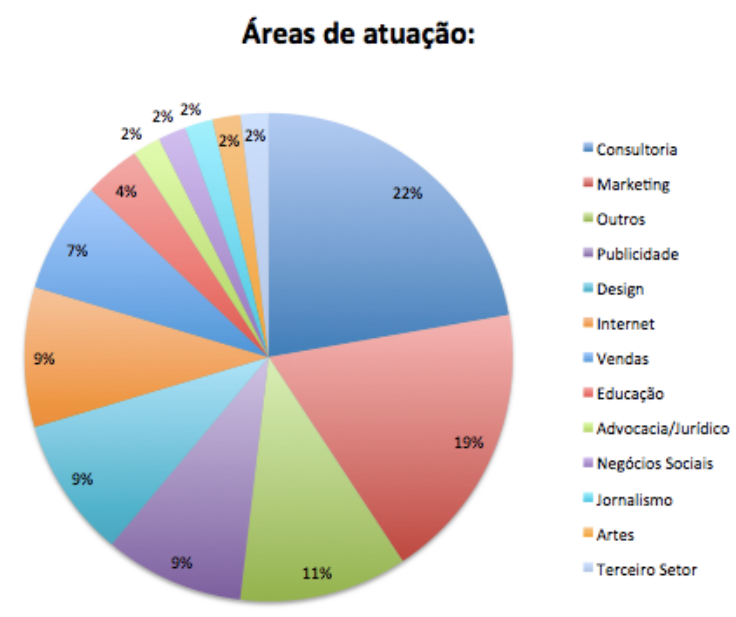


A maioria utilizou o serviço por menos de 6 meses $(50,9 \%)$ e entre 6 meses a 1 ano $(24,5 \%)$, com a estimativa pontual da média em 9 meses. Mais uma vez, confirma-se o que foi dito pelo gestor da Mères em: "na parte específica para coworking, o cliente fica em média de 6 meses a 1 ano", há certa rotatividade de empresas.

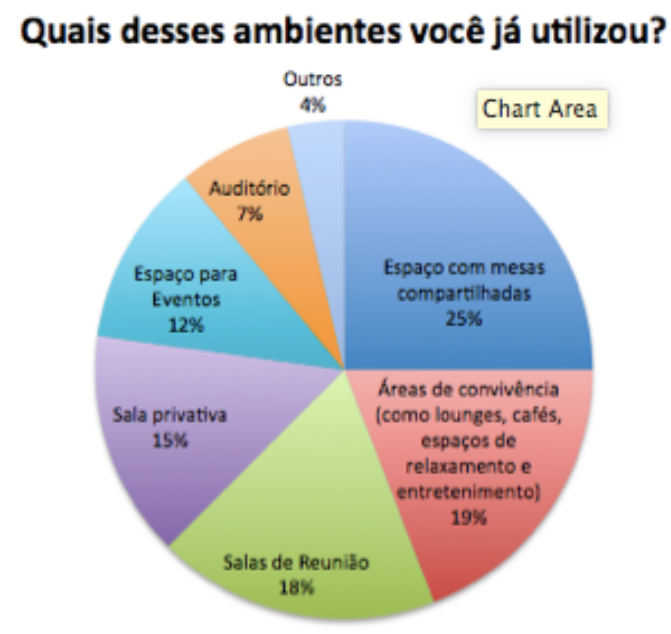

\section{Frequência de uso do serviço:}

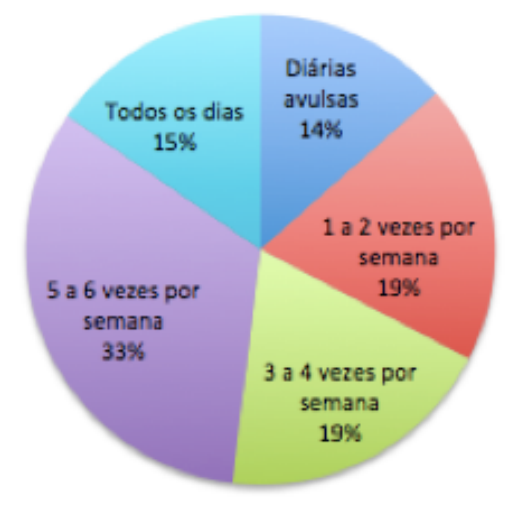

Quanto aos ambientes que mais utiliza/utilizava, podendo marcar até todas as opções, a maioria marcou: espaço com mesas compartilhadas $(64,15 \%)$, áreas de convivência (como lounges, cafés, espaços de relaxamento e entretenimento) $(49,1 \%)$ e salas de reunião $(47,2 \%)$. Alguns marcaram sala privativa $(37,7 \%)$ e espaço para eventos $(30,2 \%)$. E uma minoria marcou auditório $(18,9 \%)$. Tais dados reforçam as características dos espaços de coworking apontadas por Morisset (2014), presentes no capítulo 1.

A maioria utiliza o serviço entre 5 e 6 vezes por semana (32,7\%). Uma minoria utiliza os extremos: todos os dias $(15,4 \%)$ ou diárias avulsas $(13,5 \%)$. Isso mostra que os coworkers tendem a ser usuários fixos do espaço, mensalistas, com frequência de uso alta. E ilustra o que foi dito pelo gestor da Mères: "tem um ou outro que precisa desse acesso 24 horas / 7 dias por semana."

\subsection{Descrição e análise dos resultados do questionário}

A primeira pergunta serviu para filtrar os respondentes válidos e perguntouse "você utiliza ou já utilizou o serviço de espaços de coworking (trabalho compartilhado) na cidade do Rio de Janeiro?". A maioria (68,29\% dos respondentes) respondeu positivamente, marcando as opções "uso atualmente" e "já usei, mas não uso mais". Os outros $31,71 \%$ que marcaram "nunca usei" foram invalidados e levados ao final do questionário. Assim, 56 respondentes prosseguiram a pesquisa. 
A quinta pergunta questionava sobre o que um espaço de coworking precisa oferecer, na opinião dos respondentes, e permitiu-se marcar até todas opções, cujo resultado está no gráfico abaixo. Os atributos mais importantes, na opinião dos respondentes, foram redução de custos fixos $(80 \%)$ e infraestrutura de escritório completa ( $80 \%)$, seguidos por rede de contatos com profissionais de diversas áreas $(62,2 \%)$, proximidade da sua casa ou de clientes $(55,6 \%)$.

Em seguida, consideraram a existência dos seguintes espaços: áreas de convivência $(53,3 \%)$, salas com mesas compartilhadas $(51,1 \%)$, salas privativas $(46,7 \%)$.

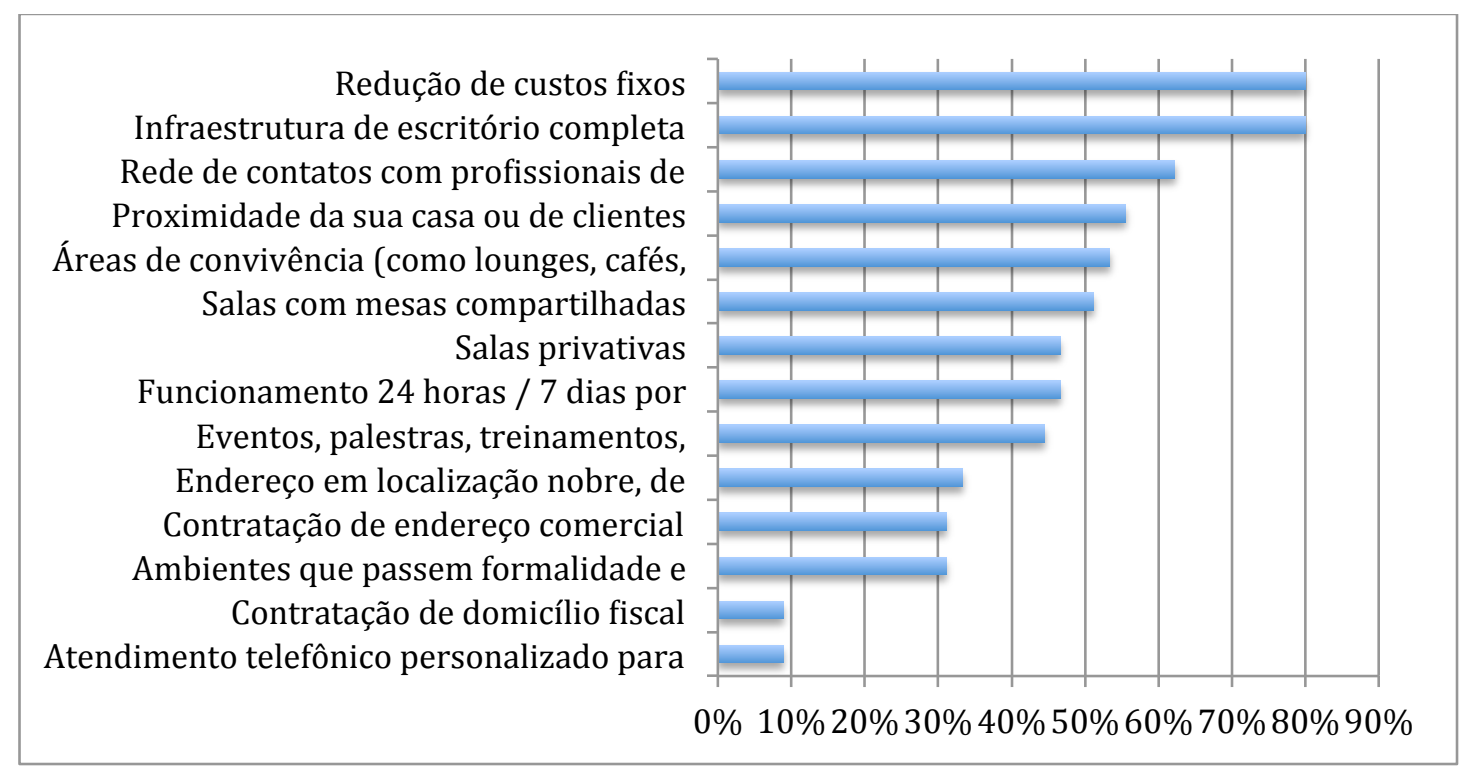

A sexta pergunta pedia para o consumidor distribuir 100 pontos de acordo com a importância que ele dá a cada atributo para o serviço. O objetivo foi medir a importância de cada uma das 5 dimensões do serviço (Hoffman \& Bateson, 2016), visando testar a hipótese dos autores para o caso do coworking.

Tabela 2: Ordem de importância das dimensões da qualidade do serviço de coworking

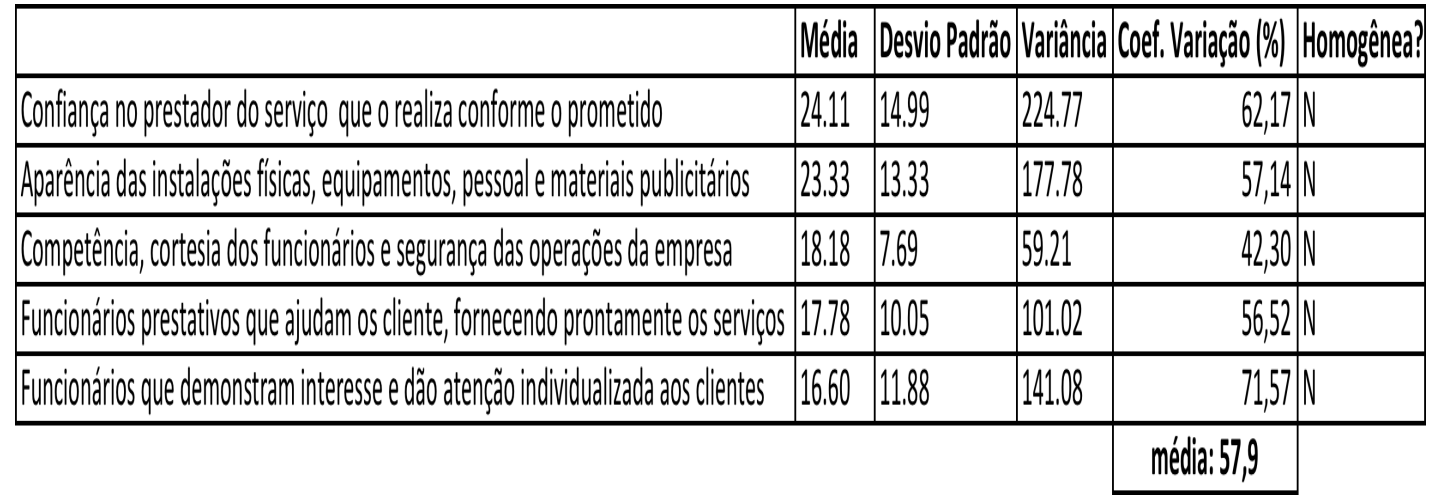

Como se vê na tabela acima, confiabilidade foi o mais valorizado pelos consumidores, assim como já previa Hoffman \& Bateson (2016). Porém, 
contrariando os autores, a tangibilidade foi o 20 mais valorizado. Isso quer dizer que, para esse serviço em específico, os aspectos tangíveis são muito importantes. E acredita-se que isso ocorre devido a dois fatores: tal serviço impacta diretamente na imagem profissional do cliente para o mercado e é um serviço que ocupa boa parte do tempo do cliente, ele passa muitas horas de seus dias trabalhando naquele espaço, então precisa estar satisfeito com o servicescape. Assim, a hipótese testada foi parcialmente validada. $O$ atributo menos valorizado para esse tipo de serviço foi empatia. Após o cálculo do coeficiente de variação, conclui-se que nenhum dos atributos teve homogeneidade nas respostas, todos deram acima de $20 \%$, com uma média de $57,9 \%$. Isso significa que as respostas foram bastante difusas.

Para analisar as perguntas 7 a 20 , que fazem parte do Servqual, destinam-se as próximas seções:

\subsubsection{Nível de expectativa do cliente sobre o serviço}

Um dos objetivos dessa pesquisa foi analisar os níveis de expectativa e de percepção dos clientes sobre o serviço de coworking. Para isso, em cada afirmativa do modelo servqual aplicado foi calculada a média ponderada das respostas assinaladas. As respostas variavam de 1 a 5 , de discordo totalmente a concordo totalmente, sendo que o peso correspondia ao grau de concordância ou discordância em relação ao item. O maior peso, 5, está na resposta concordo totalmente e o menor, 1, na resposta discordo totalmente. 0 peso 3 , que corresponde à resposta não concordo nem discordo é a medida central das respostas. Tais valores compõem o cálculo do gap. A média sempre irá assumir valores entre 1 e 5 .

As expectativas assumiram médias altas na pesquisa, o que significa que o grau de concordância dos clientes com as afirmações propostas foi alto. Isso quer dizer que os clientes têm elevada expectativa sobre o serviço. Segue, na Tabela abaixo, os valores das médias ponderadas da expectativa dos clientes por questão.

Tabela 3: Médias das expectativas dos respondentes por atributo

\begin{tabular}{|c|l|r|}
\hline \multirow{2}{*}{ Atributos } & \multicolumn{1}{|c|}{ Questões-Expectativa } & \multicolumn{1}{c|}{ Médias } \\
\hline \multirow{4}{*}{ Confiabilidade } & 10 - Quanto à solução de problemas... & 4,5 \\
\cline { 2 - 3 } & 12 - Quanto ao registro de recados & 4,3 \\
\cline { 2 - 3 } & 19 - Quanto à pontualidade... & 4,5 \\
\hline \multirow{4}{*}{ Tangibilidade } & 7 - Quanto aos equipamentos... & 4,2 \\
\cline { 2 - 3 } & 8 - Quanto às instalações físicas... & 4,4 \\
\cline { 2 - 3 } & 9 - Quanto aos materiais de comunicação... & 4,0 \\
\cline { 2 - 3 } & 11 - Quanto à vestimenta dos funcionários... & 3,4 \\
\hline Presteza & 17 - Quanto à disposição em ajudar... & 4,6 \\
\hline
\end{tabular}




\begin{tabular}{|c|l|r|}
\multirow{5}{*}{ Segurança } & 13 - Quanto a obtenção de informações... & 4,5 \\
\cline { 2 - 3 } & $\begin{array}{l}14 \text { - Quanto ao comportamento dos } \\
\text { funcionários... }\end{array}$ & 4,5 \\
\cline { 2 - 3 } & 15 - Quanto à atenção prestada... & 4,5 \\
\hline \multirow{4}{*}{ Empatia } & 16 - Quanto ao entendimento de necessidades... & 4,4 \\
\cline { 2 - 3 } & 18 - Quanto aos horários de funcionamento... & 4,7 \\
\cline { 2 - 3 } & 20 - Quanto à personalização do atendimento... & 4,0 \\
\hline
\end{tabular}

Ao observar a Tabela acima, a questão cujos clientes detêm a maior expectativa é a que assinala que os espaços excelentes terão horários de funcionamento convenientes para todos os clientes (categoria: empatia), que obteve media 4,7 . Lembrando que horário de funcionamento foi o 30 motivo mais citado pelos entrevistados na hora de optarem por um espaço de coworking e também foi citado como ponto positivo. E que um alto número $(46,7 \%)$ de clientes acham que o serviço deve ter funcionamento 24 horas / 7 dias por semana. A segunda maior expectativa foi de os funcionários estarem sempre dispostos a ajudar (categoria: presteza), que teve media 4,6 .

Já o quesito onde se tem a menor expectativa é sobre a vestimenta dos funcionários ter aparência professional (categoria: tangibilidade), que teve como média o valor 3,4 . O segundo pior quesito foi o que mede a expectativa sobre os materiais de comunicação serem visualmente atraentes (categoria: tangibilidade), alcançando uma média de 4,0. Destaca-se o fato de ambos pertencerem a dimensão da tangibilidade, citada por Hoffman e Bateson (2016) como a que é considerada menos importante, no geral. Empatado como segunda menor expectativa, há um item da dimensão empatia, a personalização do atendimento, com media 4,0. Mesmo tendo sido os mais baixos, ainda tiveram um nível de concordância positiva.

Outra análise que cabe em relação à expectativa é o seu grau por atributo da pesquisa. A Tabela abaixo relaciona a média encontrada para cada atributo importante:

Tabela 4: Médias das expectativas dos respondentes por dimensão

\begin{tabular}{|c|c|}
\hline Atributos & Média \\
\hline Confiabilidade & 4,4 \\
\hline Tangibilidade & 4,0 \\
\hline Presteza & 4,6 \\
\hline Segurança & 4,5 \\
\hline Empatia & 4.3 \\
\hline
\end{tabular}

Nessa relação, o atributo definido como de maior importância pelos clientes foi presteza, com média 4,6, indo contra a teoria (Hoffman e Bateson, 2016) que 
avalia o atributo Confiabilidade como o mais importante para qualquer serviço prestado. De qualquer maneira, a Confiabilidade, no caso da pesquisa desenvolvida neste trabalho, obteve média 4,4, considerada alta.

Em todas as 14 sentenças que avaliam a expectativa, percebe-se uma média superior a 3, que na escala denota bom índice de concordância com as assertivas, caracterizando a expectativa no serviço de coworking como alta.

\subsubsection{Nível de percepção dos cliente sobre o serviço de coworking}

A seguinte tabela mostra os dados colhidos sobre a percepção do serviço de coworking:

Tabela 5: Médias das percepções dos respondentes por atributos

\begin{tabular}{|c|l|r|}
\hline Atributos & \multicolumn{1}{|c|}{ Questões-Percepção } & \multicolumn{1}{|c|}{ Médias } \\
\hline \multirow{4}{*}{ Confiabilidade } & 10 - Quanto à solução de problemas... & 4,3 \\
\cline { 2 - 3 } & 12 - Quanto ao registro de recados & 4,0 \\
\cline { 2 - 3 } & 19 - Quanto à pontualidade... & 4,3 \\
\hline \multirow{4}{*}{ Tangibilidade } & 7 - Quanto aos equipamentos... & 4,0 \\
\cline { 2 - 3 } & 8 - Quanto às instalações físicas... & 4,1 \\
\cline { 2 - 3 } & 9 - Quanto aos materiais de comunicação... & 3,8 \\
\cline { 2 - 3 } & 11 - Quanto à vestimenta dos funcionários... & 3,5 \\
\hline \multirow{4}{*}{ Presteza } & 17 - Quanto à disposição em ajudar... & 4,4 \\
\hline \multirow{4}{*}{ Emparança } & 13 - Quanto a obtenção de informações... & 4,2 \\
\cline { 2 - 3 } & 14 - Quanto ao comportamento dos & 4,4 \\
\hline & funcionários... & 4,4 \\
\cline { 2 - 3 } & 15 - Quanto à atenção prestada... & 4,0 \\
\hline & 16 - Quanto ao entendimento de necessidades... & 4,3 \\
\cline { 2 - 3 } & 18 - Quanto aos horários de funcionamento... & 3,9 \\
\cline { 2 - 3 } & 20 - Quanto à personalização do atendimento... & \\
\hline
\end{tabular}

Observando a tabela, os itens com maior média na percepção foram 14,15 e 17, referentes aos atributos: Presteza, que mede o grau de concordância dos clientes com o fato da equipe estar sempre disposta a ajudar e Segurança, em relação ao comportamento dos funcionários e a atenção prestada pelos mesmos . Tais assertivas assumiram uma média de concordância de 4,4, o que reflete uma percepção de qualidade alta em relação aos itens. Isso mostra que os clientes acreditam que os funcionários estão sendo prestativos e os deixando seguros, no geral.

As assertivas com pior média foram as de números 9 e 11, ambas aspectos tangíveis, que medem o grau de concordância do cliente se o serviço oferecido está de acordo com a vestimenta dos funcionários e aparência dos materiais de comunicação. As médias alcançaram os valores de 3,5 e 3,8, o que caracteriza 
proximidade com neutralidade. São aspectos que poderiam melhorar, mas não são críticos, tanto que também tiveram as menores médias de expectativa.

É possível também fazer uma análise da percepção por atributo no modelo. A Tabela abaixo mostra a média da percepção para todos os atributos avaliados no questionário. $\mathrm{O}$ atributo de melhor grau de percepção pelo cliente é a presteza, que atingiu uma média de 4,4. Isso mostra que, analisando os atributos em si, a presteza é o de melhor desempenho. O pior atributo avaliado é a tangibilidade, com uma média de 3,8 . Todos os índices para a percepção têm média superior a 3 , que é o valor central da escala, o que indica que os clientes classificam o serviço prestado como de qualidade satisfatória.

Tabela 6: Médias das percepções dos respondentes por dimensão

\begin{tabular}{|c|c|}
\hline Atributos & Médias \\
\hline Confiabilidade & 4,2 \\
\hline Tangibilidade & 3,8 \\
\hline Presteza & 4,4 \\
\hline Segurança & 4,3 \\
\hline Empatia & 4,1 \\
\hline
\end{tabular}

\subsubsection{Análise de gaps em relação à qualidade percebida no} serviço de coworking:

A seguir, tem-se a tabela que mostra o valor numérico do gap referente a cada uma das 28 assertivas do questionário. Os dados mostram que apenas em uma das assertivas o gap foi negativo. Essa assertiva foi a de número 11, que trata da boa aparência da vestimenta dos funcionários do coworking. Nessa questão, a percepção do serviço, de média 3,5, supera levemente a expectativa, de média 3,4, gerando um gap de $-0,1$. Tem-se, neste quesito, a verificação da qualidade superior, uma vez que a percepção dele foi maior ou igual à expectativa referente ao mesmo.

Tabela 7: Análise dos gaps por atributos

\begin{tabular}{|c|c|c|c|c|}
\hline Atributos & Questões & Méd Exp & Méd Per & GAP \\
\hline \multirow{3}{*}{ Confiabilidade } & 10 - Quanto à solução de problemas... & 4,5 & 4,3 & 0,2 \\
\hline & 12 - Quanto ao registro de recados & 4,3 & 4,0 & 0,3 \\
\hline & 19 - Quanto à pontualidade... & 4,5 & 4,3 & 0,2 \\
\hline \multirow{4}{*}{ Tangibilidade } & 7 - Quanto aos equipamentos... & 4,2 & 4,0 & 0,2 \\
\hline & 8 - Quanto às instalações físicas... & 4,4 & 4,1 & 0,3 \\
\hline & 9 - Quanto aos materiais de comunicação... & 4,0 & 3,8 & 0,2 \\
\hline & 11 - Quanto à vestimenta dos funcionários... & 3,4 & 3,5 & $-0,1$ \\
\hline Presteza & 17 - Quanto à disposição em ajudar... & 4,6 & 4,4 & 0,2 \\
\hline \multirow{3}{*}{ Segurança } & 13 - Quanto a obtenção de informações... & 4,5 & 4,2 & 0,3 \\
\hline & 14 - Quanto ao comportamento dos funcionários... & 4,5 & 4,4 & 0,1 \\
\hline & 15 - Quanto à atenção prestada... & 4,5 & 4,4 & 0,1 \\
\hline \multirow{3}{*}{ Empatia } & 16 - Quanto ao entendimento de necessidades... & 4,4 & 4,0 & 0,4 \\
\hline & 18 - Quanto aos horários de funcionamento... & 4,7 & 4,3 & 0,4 \\
\hline & 20 - Quanto à personalização do atendimento... & 4,0 & 3,9 & 0,1 \\
\hline
\end{tabular}


Em todos os demais casos, o gap se configurou positivo, o que implica dizer que a percepção foi menor que a expectativa e a qualidade do serviço pode ser caracterizada como abaixo das expectativas (BERRY; PARASURAMAN; ZEITHAML, 1985). O maior gap $(0,4)$ se deu nas questões de números 16 e 18 , ambas da dimensão empatia que tratam, respectivamente, do entendimento de necessidades específicas do cliente e dos horários de funcionamento. Mesmo o maior gap não pode ser considerado um valor alto, ou seja, a qualidade do serviço de espaços de coworking deixa muito levemente a desejar em relação ao esperado.

A tabela abaixo, mostra o cálculo do gap por dimensões, que levará ao gap final, que mede a qualidade total do serviço em questão.

Tabela 8: Análise dos gaps por dimensões

\begin{tabular}{|c|c|c|c|}
\hline Atributos & Méd Exp & Méd Per & GAP \\
\hline Confiabilidade & 4,4 & 4,2 & 0,2 \\
\hline Tangibilidade & 4,0 & 3,8 & 0,2 \\
\hline Presteza & 4,6 & 4,4 & 0,2 \\
\hline Segurança & 4,5 & 4,3 & 0,2 \\
\hline Empatia & 4,3 & 4,1 & 0,2 \\
\hline
\end{tabular}

Como pode ser visto na tabela, tiveram médias altas de expectativa, próximas a máxima que seria 5 e também médias altas de percepção, porém sempre sendo superadas pela expectativa.

Curiosamente, os gaps deram iguais para todas as dimensões da qualidade de serviços, logo, o gap final tem valor de 0,2 , muito próximo à qualidade aceitável que seria gap nulo, porém ainda um pouco aquém, podendo considerar a qualidade do serviço de espaços de coworking na cidade do RJ um pouco inferior à esperada.

Isso também significaria dizer que os prestadores desse serviço devem focar esforços em melhorar igualmente todos esses atributos, para superar as expectativas de seus clientes e enfrentar melhor uma futura concorrência de novos espaços, num mercado que está em crescimento. Porém, como analisamos previamente (pergunta 6) a importância relativa entre as dimensões, concluímos que, nesse caso, deve-se dar uma maior atenção à duas delas: a confiabilidade no prestador de serviço, que deve realizar o mesmo conforme o prometido e a tangibilidade, gerenciando bem a aparência dos equipamentos, instalações físicas, materiais de comunicação e quaisquer outros elementos visuais do local. 


\subsubsection{Análise final comparativa:}

Percebe-se que existem 3 tipos diferentes de finalidade dos espaços: foco no coworking puro, foco em escritórios virtuais e salas privativas corporativas e espaços híbridos. Pelo perfil traçado na etapa quantitativa, percebe-se que, ainda que haja uma procura crescente por salas privativas (como viu-se no capítulo 1 e na fala da gestora do Nex), com $46,7 \%$ dos respondentes do questionário considerando-as essenciais, os espaços de trabalho com mesas compartilhadas ainda é um pouco mais procurado, com $51,1 \%$ dos respondentes do questionário considerando-os essenciais .

O servicescape deverá ser adequado ao estilo/perfil do público-alvo. Nas entrevistas, houve um empate entre clientes que procuram ambiente corporativo e os que preferem um ambiente informal. Na etapa qualitativa, $31,1 \%$ dos coworkers marcaram a necessidade de ambientes formais. Conclui-se que essa preferência vai depender da profissão do cliente e área de atuação da sua empresa.

Com as entrevistas vimos que os motivos que mais levam a optar pelo coworking são, em ordem de importância: networking, infraestrutura, custo-benefício e horário de funcionamento.

E os atributos considerados pontos positivos dos espaços foram, em ordem de importância: networking; infraestrutura; ambiente e equipe; eventos, horário de funcionamento e localização; ambiente informal, colaboração, custo-benefício, evitar distrações e quebrar o isolamento, flexibilidade contratual.

O ponto negativo mais citado foi: baixo engajamento da comunidade. As demais desvantagens igualmente apresentadas foram: falta de privacidade, regras, problemas na infraestrutura, gestão do silêncio, localização, custo-benefício, erros no registro de recados, área de convivência pequena, distrações, disputa por salas de reunião, poucos eventos com objetivo profissional.

Como dito por Hoffman \& Bateson (2016) em todo serviço há desafios críticos da gestão e percebemos que o maior desafio desse serviço, apontado pelos gestores do Templo e do Nex é gerir a comunidade, o engajamento dos coworkers entre si e nas atividades que estimulam as interações de networking. Os entrevistados apontaram ser essa dificuldade um ponto negativo do serviço. E, devemos lembrar que $62,2 \%$ dos respondentes acham essencial oferecer esse networking com profissionais de diversas áreas, tendo sido um dos 3 atributos mais citados. Logo, trata-se de um ponto crítico, que deve ser melhor gerenciado para entregar qualidade aos clientes.

Pontos negativos do coworking, citados tanto pelo gestor da Mères, quanto nas entrevistas são: a gestão do silêncio e a grande movimentação de pessoas e 
informações que atrapalha a concentração do coworker. Quanto à gestão do silêncio, a alternativa adotada pelo Nex. pode ser replicada em outras empresas. Curiosamente, enquanto $11 \%$ dos entrevistados acha que o coworking evita distrações, outros $11 \%$ acham que aumenta a distração.

A infraestrutura de escritório completa foi o 20 atributo mais essencial que um coworking precisa oferecer, tanto na opinião dos respondentes do questionário $(80 \%)$ quanto na dos entrevistados $(55,6 \%)$. Então, ela impacta muitíssimo na percepção da qualidade desse serviço. Porém, ela parece estar sendo bem gerenciada pois foi vista por $44 \%$ dos entrevistados como ponto positivo do serviço e apenas $11 \%$ como negativo.

Conclui-se que a relação custo-benefício do coworking deve ser melhor do que se a pessoa alugasse uma sala comercial fora de coworking. Esse foi o 30 atributo mais considerado pelos entrevistados para optar pelo coworking. Na opinião dos respondentes do questionário, a redução de custos fixos é o atributo mais importante que um coworking precisa oferecer. Logo, a formação de preços é um ponto crítico para a qualidade percebida.

A localização também é um atributo muito importante para os consumidores, tendo sido, na opinião dos respondentes do questionário, o $3^{\circ}$ atributo mais importante que um coworking precisa oferecer (proximidade da sua casa ou de clientes). Endereço em localização nobre também foi um atributo considerado por alguns respondentes. Além disso, localização foi citada nas 3 perguntas das entrevistas, tanto como motivo para procurar espaço de coworking, quanto como ponto positivo por $22 \%$ e como desvantagem por $11 \%$.

O horário de funcionamento também é um atributo importante para os consumidores, tendo sido, na opinião dos respondentes do questionário, o 60 atributo mais importante que um coworking precisa oferecer $(46,7 \%)$. Além disso, o horário foi citado nas entrevistas, tanto como motivo para procurar espaço de coworking, quanto como ponto positivo por $22 \%$. Não houve reclamação quanto a esse atributo, mas deve-se considerar que todos os entrevistados usavam espaços $24 \mathrm{~h} / 7$.

Comparando as 3 etapas, percebe-se que a faixa etária que prevalece é de jovens adultos. Eles tem profissões diversas, mas a maioria trabalha em startups $(33,3 \%)$, consultoria $(28,6 \%)$ e marketing $(23,8 \%)$. A maioria pertence a setores criativos e tecnológicos, tendência apontada por Morisset (2014).

A maioria dos entrevistados usa o serviço há menos de 6 meses (44\%). Verificou-se que há rotatividade entre usuários de espaços compartilhados, como 
apontado pelo gestor da Mères. E a frequência de uso é bastante alta, entre 5-6 vezes por semana, com maior parte sendo mensalista.

Em relação aos ambientes utilizados, as respostas dos entrevistados e dos respondentes do questionário tiveram resultados diferentes em termos de posição e em percentual.

O mais utilizado segundo a etapa quantitativa foi espaço com mesas compartilhadas $(64,15 \%)$. Enquanto que, na qualitativa, houve um empate entre (89\%) áreas de convivência e $(89 \%)$ salas de reunião.

O segundo mais utilizado segundo a etapa quantitativa foi áreas de convivência (49,1\%). Enquanto que, na qualitativa, houve um empate entre espaço com mesas compartilhadas $(67 \%)$ e salas privativas $(67 \%)$.

O terceiro mais utilizado segundo a etapa quantitativa foi salas de reunião $(47,2 \%)$. Já na qualitativa, foi espaço para eventos (56\%).

O quarto mais utilizado segundo a etapa quantitativa foi sala privativa $(37,7 \%)$.

O quinto mais utilizado segundo a etapa quantitativa foi espaço para eventos $(30,2 \%)$.

O único consenso entre os resultados foi o último colocado, auditório, utilizado por uma minoria de $(18,9 \%)$ na etapa quantitativa e $11 \%$ na qualitativa.

Oficialmente, serão consideradas as respostas da etapa quantitativa, pelo maior número de ocorrências. Assim, os espaços de cowoking devem ter primordialmente espaços com mesas compartilhadas, áreas de convivência (como lounges, cafés, espaços de relaxamento e entretenimento) e salas de reunião, confirmando o apontamento de Moriset sobre as características dos coworkings (2014).

Apesar de um pouco menos considerada pelos respondentes, devemos lembrar que o Censo Coworking Brasil 2016 e o relato dos gestores de 2 espaços visitados, mostraram que há um grande crescimento na demanda por salas privativas. E que alguns entrevistados reclamaram de falta de privacidade como ponto negativo do coworking, então conclui-se que o público que quer trabalhar com privacidade, tem motivos para demandar salas privativas.

E quanto aos espaços para eventos, ainda menos considerados, deve-se levar em conta que algumas vezes, a própria área de convivência se torna um espaço para eventos, então alguns respondentes podem ter considerado assim. Também deve-se levar em conta que os entrevistados da etapa qualitativa falaram muito sobre a importância e a dificuldade de se estabelecer uma rede de coworkers (networking) engajada, conectada, considerando isso um ponto negativo. Através de 
eventos, geram-se mais momentos de interação que possibilitam isso. Além disso, os eventos foram citados por alguns entrevistados como ponto positivo dos espaços de coworking, considerados essenciais por $44 \%$ dos coworkers que responderam ao questionário.

Nem todos os espaços deverão oferecer auditório, sugere-se fazer um estudo da demanda. Pode ter ocorrido uma dificuldade dos respondentes em diferenciar auditório e espaço para eventos, prejudicando os resultados, fato que só foi percebido na análise dos resultados.

Entre as 5 dimensões da qualidade de serviços, a confiabilidade foi o mais valorizado pelos consumidores. Um dos entrevistados reclamou de erros nos registros de recados, que é um item de confiabilidade e, na análise do gap, a questão de registro de recados teve o maior gap positivo da categoria confiabilidade. Então pode ser considerado ponto crítico a ser melhorado. A tangibilidade foi o 20 mais valorizado. Isso quer dizer que, para esse serviço em específico, os aspectos tangíveis são muito importantes. Percebemos isso, na etapa das entrevistas, a menção a vários itens tangíveis, como: infraestrutura, ambiente, ambiente corporativo, ambiente informal. E também no Servqual, nas médias altas de expectativa em relação a itens tangíveis, com média 4 . Foi o atributo com a pior média de percepção, então é um fator crítico a ser melhorado para aferição de qualidade. Sendo assim, há de se ter um foco mais imediato para melhorar a qualidade nesses 2 aspectos.

Questões relativas ao aspecto segurança não foram citadas pelos entrevistados nem citadas ou observadas na etapa 1. Entende-se que não há o que melhorar em relação a qualidade de tal dimensão, que obteve altas médias de expectativa mas também de percepção.

Quanto à presteza, na etapa de entrevistas, a presteza da equipe foi o 30 ponto mais citado como positivo. Foi o atributo que teve maior expectativa dos clientes, mas também teve a melhor média de percepção. Então não constitui fator crítico a ser melhorado, mas é muito importante na avaliação da qualidade.

$\mathrm{O}$ atributo considerado menos importante para esse serviço foi empatia. Nas entrevistas, ele foi mencionado apenas em termos de se ter horário de funcionamento conveniente a todos. Mas deve-se lembrar que o horário de funcionamento é um atributo considerado importante, tendo sido, na opinião dos respondentes do questionário, o 60 atributo mais importante que um coworking precisa oferecer $(46,7 \%)$ e tendo tido, na Servqual, o maior gap de todos os itens. Assim, tal aspecto pode e deve ser melhorado. E já está sendo, pois, como visto no capítulo 1, subiu, em 2016, o número de espaços que funcionam $24 \mathrm{~h}$ por dia. 
Destaca-se que os gaps de todas as categorias deram o mesmo valor: 0,2, sendo um valor positivo, mas muito próximo a 0 . Assim, consideraremos que todos os atributos estão apenas levemente abaixo do esperado pelos consumidores de espaço de coworking. Podem ser melhorados, mas sem muita gravidade.

Conclui-se então, que há de se ter um foco mais imediato para melhorar a qualidade em relação a tais aspectos: networking, infraestrutura, custo-benefício, confiabilidade, principalmente em relação a erros nos registros de recados e itens tangíveis, principalmente em relação a aparência das instalações físicas. 


\section{Conclusões e recomendações para novos estudos}

Este capítulo resume as principais contribuições produzidas ao tema em estudo.

No capítulo 1, definiu-se o que são espaços de trabalho compartilhado (coworking) e mostrou-se o crescimento desse setor no Brasil, com recente expansão para Rio de Janeiro. Também definiu-se o público-alvo do serviço, trabalhadores criativos, porém servindo a empresas e profissionais de diversas áreas. Falou-se também sobre a importância da localização, custo-benefício e do foco em promover networking, além de outras estatísticas colhidas em pesquisas do setor. Concluiu-se que o cenário é favorável à expansão do movimento no Rio de Janeiro e que faltam estudos sobre a avaliação da qualidade desse serviço pelo consumidor de tais espaços. Assim, o objetivo desse estudo foi compreender que fatores mais influenciam a qualidade percebida por consumidores de espaços de coworking no Rio de Janeiro. E para isso, foram identificadas diferenças e semelhanças entre os espaços, perfis dos consumidores e nível de expectativa e percepção dos clientes.

Para aprofundar a análise pretendida, investigou-se as perspectivas de Grönroos (1993) e de Hoffman e Bateson (2016) sobre a definição e as características de serviços quanto a de de Hoffman e Bateson (2016) e Groonros (1993) para gestão da qualidade em serviços. Posteriormente, falou-se da teoria de Berry, Parasuraman e Zeithaml (1985) sobre as 5 lacunas (gaps) de falha na qualidade do serviço, definindo cada uma segundo Hoffman e Bateson (2016) e Gronroos (1993). Concluiu-se que, para esse estudo, seria relevante calcular a $5^{\text {a }}$ lacuna, que é o gap na qualidade percebida do serviço, medindo a distância entre expectativas e percepções do cliente em relação ao serviço. Também explicou-se o Servqual, criado por Berry, Parasuraman \& Zeithaml (1988), que avalia a qualidade dos serviços através de cinco dimensões: tangibilidade, confiabilidade, presteza, segurança e empatia. Tal modelo foi usado na etapa de análise quantitativa e também testou-se tendência apontada por Hoffman e Bateson (2016).

Para atingir aos objetivos pretendidos realizou-se pesquisa de campo e levantamento. Foi realizada uma observação participante em 3 espaços de coworking, usando roteiro de observação direta das atividades e fotos tiradas pela 
pesquisadora, 9 entrevistas totalmente estruturadas com respostas abertas com clientes desses espaços e, por último, um questionário, pré-testado, com 23 questões fechadas e coleta online, distribuído em 20 grupos em redes sociais. Obteve-se um total de 82 respostas, com 56 válidas. Os dados foram tratados através de: análise das fotos e anotação das características observadas em visita aos espaços, análise de conteúdo das entrevistas e análise de frequência e cálculo de médias e gaps, para o questionário, usando a ferramenta Excel.

Em relação aos resultados, comparando as 3 etapas, percebe-se que a faixa etária que prevalece é de jovens adultos que trabalham em setores criativos e tecnológicos, como apontou Morisset (2014). Há uma certa rotatividade de empresas em espaços compartilhados. A frequência de uso é bastante alta, predominando clientes mensalistas.

Confirmou-se que espaços de cowoking devem ter primordialmente espaços de trabalho com mesas compartilhadas, áreas de convivência e salas de reunião. $E$ conclui-se que há também um público que quer trabalhar com privacidade, tendo motivos para demandar salas privativas, o que acredita-se justificar o aumento dessa demanda. O servicescape poderá variar de acordo com os diferentes perfis de público-alvo.

Dentre as principais questões abordadas salientam-se que os motivos que mais levam as pessoas a optar pelo coworking são, em ordem de importância: networking, infraestrutura, custo-benefício e horário de funcionamento. $E$ os atributos mais considerados pontos positivos foram, em ordem de importância: networking; infraestrutura; ambiente e equipe; eventos, horário de funcionamento e localização. Já o ponto negativo mais citado foi baixo engajamento da comunidade e as demais desvantagens foram pouco citadas.

O maior desafio crítico da gestão desse serviço é em relação a networking, atributo dos mais valorizados pelos clientes: o desafio é gerir o engajamento e as interações da comunidade. Melhorar esse ponto impactará positivamente na melhora da qualidade geral do serviço.

Redução de custos fixos foi considerado o atributo mais importante que um coworking precisa oferecer, logo, a formação de preços é um ponto crítico para a qualidade percebida. Localização e horário de funcionamento também são atributos importantes para os consumidores.

Entre as 5 dimensões da qualidade de serviços, a confiabilidade foi a mais valorizada pelos consumidores. E os erros nos registros de recados foram considerados ponto crítico dessa dimensão a ser melhorado. 
A tangibilidade foi a segunda dimensão mais valorizada, então para esse serviço em específico, os aspectos tangíveis são muito importantes. A infraestrutura, por exemplo, foi o 20 atributo mais essencial que um coworking precisa oferecer. E a aparência das instalações físicas é um fator crítico dessa dimensão a ser melhorado para aferição de qualidade.

Assim, confirmou-se apenas parcialmente a hipótese de Hoffman e Bateson (2016) sobre a importância das dimensões.

Conclui-se então, que há de se ter um foco mais imediato para melhorar a qualidade em relação a tais aspectos: networking, infraestrutura, custo-benefício, confiabilidade, principalmente em relação a erros nos registros de recados e itens tangíveis, principalmente em relação a aparência das instalações físicas.

\subsection{Sugestões e recomendações para novos estudos}

Como o coworking é um tipo de serviço que está crescendo no Brasil, encoraja-se a realização de pesquisas posteriores, podendo-se até fazer um comparativo com esta, analisando a evolução do setor ou aspectos mais específicos do serviço, não apenas com abordagem de marketing mas também de organizações, recursos humanos, finanças.

Podem ser feitas pesquisas em âmbito regional ou nacional, com diversas finalidades. Futuramente, à medida que esse mercado chegar a maturidade, haverão mudanças e novas conclusões poderão ser tiradas. 


\section{Referências Bibliográficas}

ANCEV - Associaçāo Nacional de Coworking e Escritórios Virtuais. Escritorios Compartilhados. 2016. Disponível em: < http://www.ancev.org.br/escritorio-virtual/ >. Acesso em: 12 jun. 2016.

ARKIN, H.; COLTON, R. Apud TAGLIACARNE, G. Pesquisa de mercado. São Paulo: Atlas, 1976. p. 176.

BATESON, J. \& HOFFMAN, K. Princípios de marketing de serviços: conceitos, estratégias e casos. Sāo Paulo: Cengage Learning, 2016.

BERRY, LEONARD L.; PARASURAMAN, A; ZEITHAML, VALARIE A. A Conceptual Model of Service Quality and Its Implications for Future Research. Journal of Marketing, American Marketing Association. Vol. 49, 41-50. Fall, 1985.

BERRY, LEONARD L.; PARASURAMAN, A; ZEITHAML, VALARIE A. Servqual: A Multiple-Item Scale For Measuring Customer Perceptions of Service Quality. Journal of Retailing, 64, 1, 1988, p. 12-40.

COWORKING BRASIL. Plataforma colaborativa sobre coworking. Rio de Janeiro, 2016. Disponível em: <https://coworkingbrasil.org/como-funciona-coworking/>. Acesso em 12 de jun. 2016.

COWORKING BRASIL. Censo Coworking Brasil 2016. 2016. Disponível em: < https://coworkingbrasil.org/censo/ >. Acesso em: 12 de maio. 2006.

FITZSIMMONS, JAMES A.; FITZSIMMONS, MONA J. Administraçāo de Serviços - Operações, Estratégia e Tecnologia da Informaçāo. $4^{a}$ edição. Porto Alegre: Bookman, 2004.

Florida, R. The Rise Of The Creative Class: And How It's Transforming Work, Leisure, Community And Everyday Life. United States: Basic Books, 2002.

Gil, Antonio C.. Como Elaborar Projetos de Pesquisa. São Paulo: Editora Atlas, 4a edição, 2002.

GRÖNROOS, C. Marketing: Gerenciamento e Serviços. Rio de Janeiro: Campus, 1993.

LOVELOCK, C. \& WRIGHT, L. Serviços: marketing e gestão. Sāo Paulo: Saraiva, 2005. 
Lumley, R. M. Coworking project in the campus library: supporting and modeling entrepreneurial activity in the academic library. New Review of Academic Librarianship, 20(1), 40, 2014.

Malecki, E. e Moriset, B. The digital economy: business organization, production processes and regional developments. London: Routledge, 2007.

Moriset, B. Building new places of the creative economy: The rise of coworking spaces. 2nd geography of innovation international conference 2014 (p. 1-25). Utrecht, 2014. Recuperado de https://halshs.archives-ouvertes.fr/ halshs00914075/document

Oldenburg, R. The Great Good Place: Cafes, Coffee Shops, Bookstores, Bars, Hair Salons, and Other Hangouts at the Heart of a Community. New York: Paragon House, 1989.

Open Street Map Contributors. Global Coworking Map. Brasil, 2015. Disponível em: < http://coworkingmap.org/?s=Brasil>. Acesso em: 25 de maio. 2016.

Soares, J. M. M. \& Saltorato, P. Coworking, uma forma de organização de trabalho: conceitos e práticas na cidade de São Paulo. AtoZ: novas práticas em informação e conhecimento, 4(2), $61 \quad$ - 73, 2015. Recuperado de: http://dx.doi.org/10.5380/atoz.v4i2.42337

VEIGA, Luciana S.; FARIAS, Josivania S.. Avaliação da Qualidade dos Serviços em uma Pousada com a Aplicação da Escala Servqual. Turismo - Visão e Ação. V. 7, n. 2, p. 257 a 272, maio/agosto, 2004. 


\section{Anexo 1}

\section{1 - Roteiro de observação participante:}

Os itens a ser observados nesta etapa serão:

Tamanho do local e Localização

Número de empresas clientes

Equipe (aparência, cargos e áreas de atuação)

Relação e comunicação entre coworkers e equipe

Ambientes (espaços, estilo da decoração, cheios ou vazios)

Estilo (mais ou menos formal, espaços abertos/fechados, áreas de convivência, restaurantes/lanchonetes, local para eventos, jardim, recepção, estado de conservação, aparência: moderna / antiga / limpa/ suja/ organizada/ desorganizada)

Perfis dos usuários (profissões, faixa etária, áreas das empresas, estilo de vestir)

Comportamentos (jeito de falar, tribos, formal/informal, comportamento no uso de espaços e nas interações pessoais)

Planos/serviços que mais utilizam

Quanto tempo permanecem no espaço

Atividades e Eventos para comunidade (reuniões, workshops, palestras, lanches, happy-hours, gratuitos ou não)

Nível de interação da comunidade

\section{2 - Fotos:}

\section{Templo:}




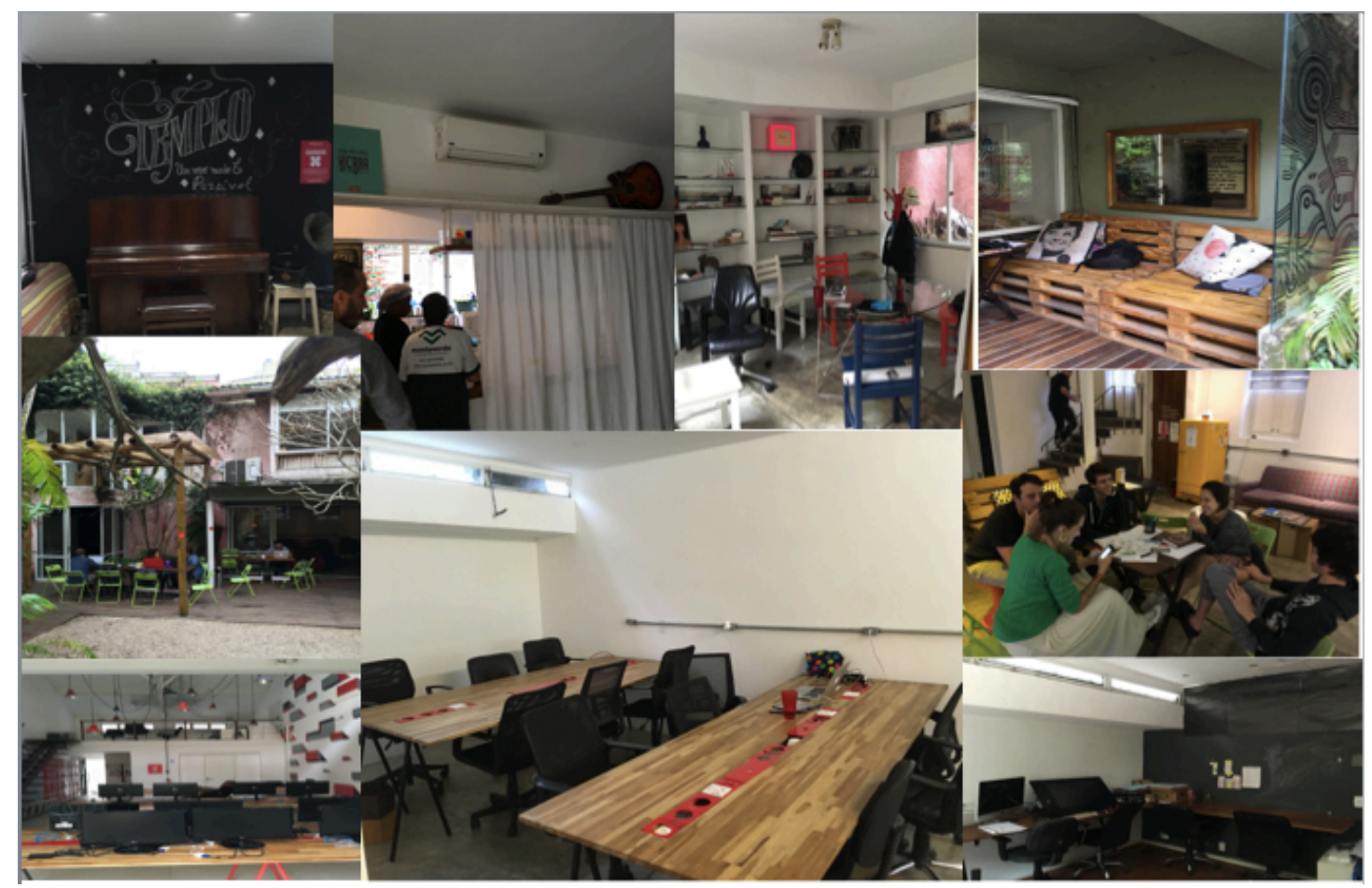

\section{Mères:}

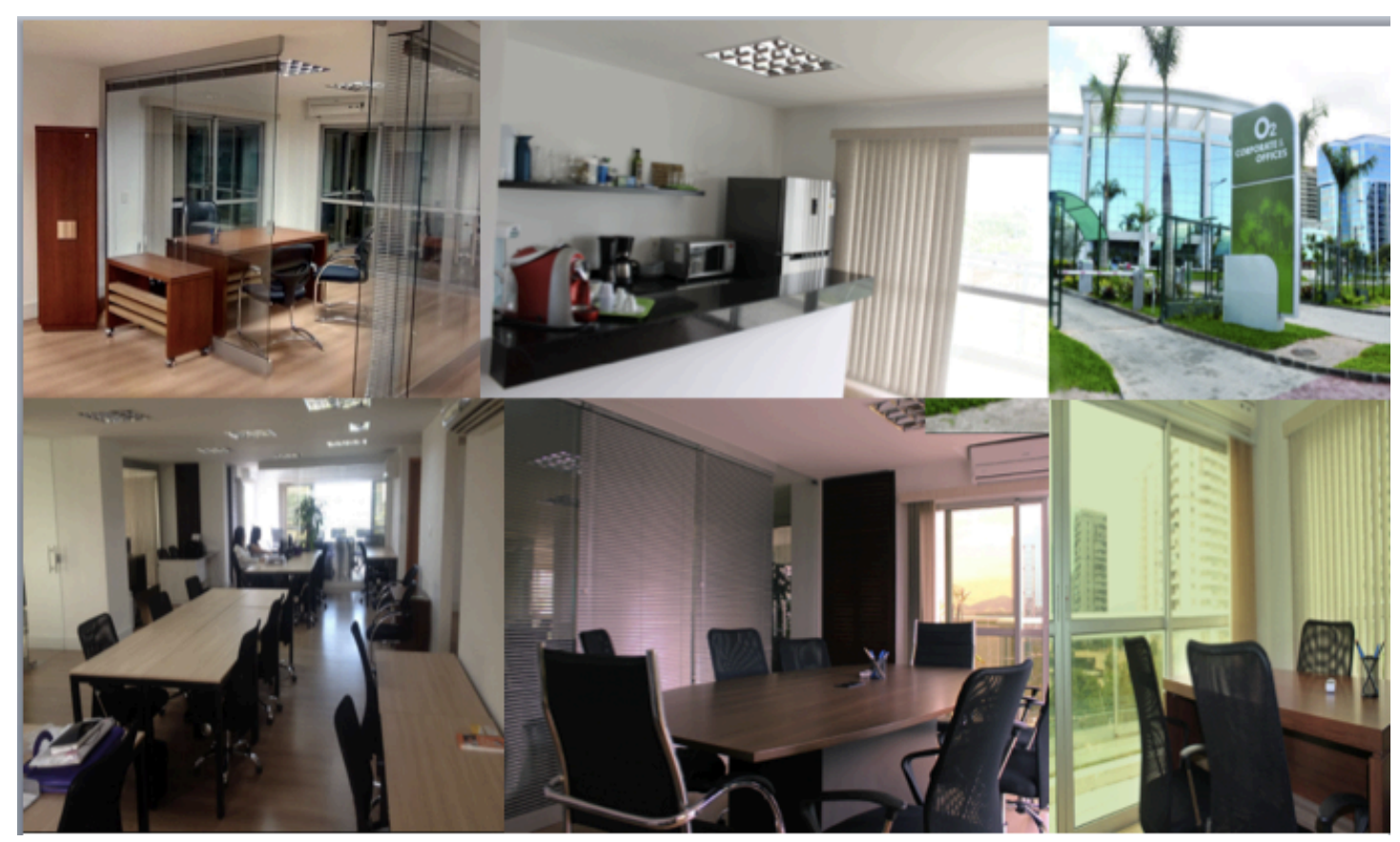

Nex: 


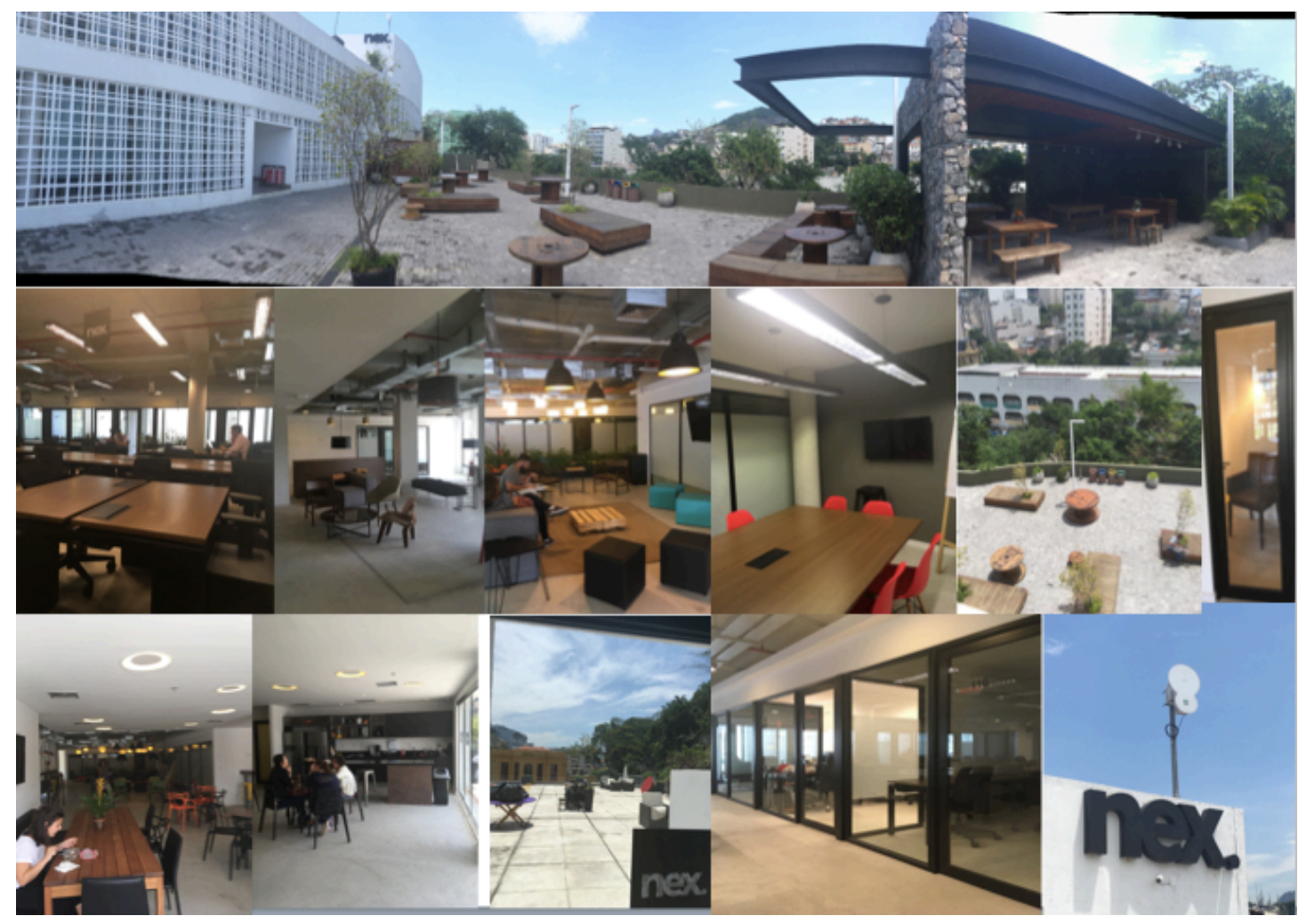

\section{3 - Questionário:}

Questionário sobre qualidade de espaços de coworking na cidade do RJ

O objetivo dessa pesquisa é levantar as percepções de clientes de espaços de coworking (trabalho compartilhado) na cidade do Rio de Janeiro, sobre a qualidade deste serviço, com o objetivo de gerar apontamentos que contribuam para a melhoria ou manutenção do nível de qualidade do mesmo, identificando os fatores que são mais importantes nessa avaliação. O importante é saber a sua opinião, não há resposta certa ou errada.O registro é anônimo e você não levará mais que 8 minutos respondendo às questões. Obrigada, desde já!Vamos começar? 
1 Você utiliza ou já utilizou o serviço de espaços de coworking (trabalho compartilhado), na cidade do Rio de Janeiro?

O Uso atualmente (1)

O Já usei, mas não uso mais (2)

O Nunca usei (3)

If Nunca usei Is Selected, Then Skip To End of Survey 
2 Qual (is) desses ambientes você já utilizou? [marque quantas opções desejar]

Sala privativa (1)

- Espaço com mesas compartilhadas (2)

口 Salas de Reunião (3)

auditório (4)

- Espaço para Eventos (5)

- Áreas de convivência (como lounges, cafés, espaços de relaxamento e entretenimento) (6)

a Outros (7)

3 Por quanto tempo utilizou ou vem utilizando o serviço?

O Menos de 6 meses (1)

O 6 meses - 1 ano (2)

O 1 ano -1 ano e meio (3)

O 1 ano e meio - 2 anos (4)

Mais de 2 anos (5)

4 Com que frequência utilizou ou vem utilizando o serviço?

O Diárias avulsas (8)

O 1 a 2 vezes por semana (1)

O 3 a 4 vezes por semana (2)

O 5 a 6 vezes por semana (3)

Todos os dias (6) 
5 Para você, o que um espaço de coworking precisa oferecer? [marque quantas opções desejar]

Rede de contatos com profissionais de diversas áreas, proporcionando troca de experiências e parcerias (1)

- Infraestrutura de escritório completa (ex: móveis, manutenção, suporte de internet, impressoras, recepcionista) (2)

- Funcionamento 24 horas / 7 dias por semana (3)

- Reduçāo de custos fixos (4)

Endereço em localizaçāo nobre, de prestígio (5)

- Proximidade da sua casa ou de clientes (6)

Eventos, palestras, treinamentos, workshops, cursos (7)

- Ambientes que passem formalidade e profissionalismo (8)

- Áreas de convivência (como lounges, cafés, espaços de relaxamento e entretenimento) (9)

- Atendimento telefônico personalizado para sua empresa (11)

- Contratação de endereço comercial (12)

- Contratação de domicílio fiscal (13)

Salas privativas (10)

- Salas com mesas compartilhadas (14)

6 Distribua 100 pontos de acordo com a importância de cada atributo para o serviço:

Confiança no prestador do serviço, que o realiza conforme o prometido

Funcionários prestativos, que ajudam os clientes, fornecendo prontamente os serviços (2)

Aparência das instalações físicas, equipamentos, pessoal e materiais publicitários (3)

Competência, cortesia dos funcionários e segurança das operações da empresa (4)

Funcionários que demonstram interesse e dão atenção individualizada aos clientes (5) 
Responda às questões das próximas páginas de acordo com sua avaliação do serviço que seria ideal vs. o serviço realmente prestado pelo(s) espaço(s) de coworking que você já utilizou...

7 Quanto aos equipamentos...

\begin{tabular}{|c|c|c|c|c|c|}
\hline & $\begin{array}{l}\text { Concordo } \\
\text { Totalmente } \\
\text { (1) }\end{array}$ & $\begin{array}{c}\text { Concordo } \\
\text { em Parte } \\
\text { (2) }\end{array}$ & $\begin{array}{c}\text { Não } \\
\text { Concordo } \\
\text { Nem } \\
\text { Discordo } \\
\text { (3) }\end{array}$ & $\begin{array}{c}\text { Discordo } \\
\text { em Parte } \\
\text { (4) }\end{array}$ & $\begin{array}{c}\text { Discordo } \\
\text { Totalmente } \\
\text { (5) }\end{array}$ \\
\hline $\begin{array}{l}\text { Excelen } \\
\text { tes espaços } \\
\text { de coworking } \\
\text { terão } \\
\text { equipamentos } \\
\text { modernos (1) }\end{array}$ & 0 & 0 & 0 & 0 & 0 \\
\hline $\begin{array}{l}\text { O } \\
\text { espaço que } \\
\text { utilizo possui } \\
\text { equipamentos } \\
\text { modernos (2) }\end{array}$ & 0 & 0 & 0 & 0 & 0 \\
\hline
\end{tabular}


8 Quanto às instalações físicas...

\begin{tabular}{|c|c|c|c|c|c|}
\hline & $\begin{array}{l}\text { Concordo } \\
\text { Totalmente } \\
\text { (1) }\end{array}$ & $\begin{array}{c}\text { Concordo } \\
\text { em Parte } \\
\text { (2) }\end{array}$ & $\begin{array}{c}\text { Não } \\
\text { Concordo } \\
\text { Nem } \\
\text { Discordo } \\
\text { (3) }\end{array}$ & $\begin{array}{c}\text { Discordo } \\
\text { em Parte } \\
\text { (4) }\end{array}$ & $\begin{array}{l}\text { Discordo } \\
\text { Totalmente } \\
\text { (5) }\end{array}$ \\
\hline 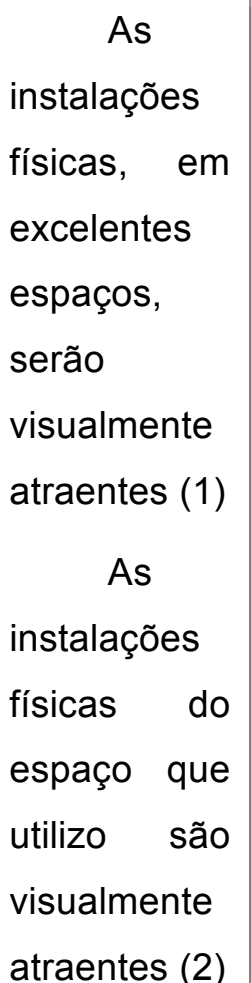 & 更 & 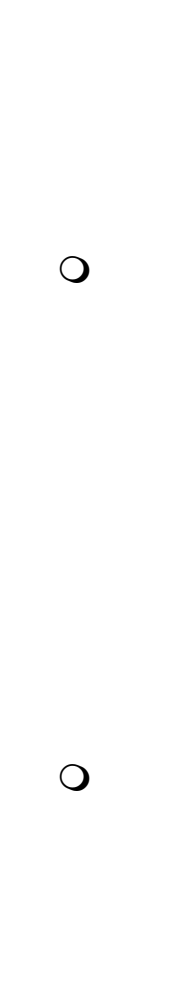 & 0 & 0 & 0 \\
\hline
\end{tabular}


9 Quanto aos materiais de comunicação...

\begin{tabular}{|c|c|c|c|c|c|}
\hline & $\begin{array}{l}\text { Concordo } \\
\text { Totalmente } \\
\text { (1) }\end{array}$ & $\begin{array}{c}\text { Concordo } \\
\text { em Parte } \\
\text { (2) }\end{array}$ & $\begin{array}{c}\text { Não } \\
\text { Concordo } \\
\text { Nem } \\
\text { Discordo } \\
\text { (3) }\end{array}$ & $\begin{array}{c}\text { Discordo } \\
\text { em Parte } \\
\text { (4) }\end{array}$ & $\begin{array}{l}\text { Discordo } \\
\text { Totalmente } \\
\text { (5) }\end{array}$ \\
\hline $\begin{array}{l}\text { Materia } \\
\text { is de } \\
\text { comunicação } \\
\text { (folders, } \\
\text { panfletos, } \\
\text { etc.) de um } \\
\text { excelente } \\
\text { espaço serão } \\
\text { visualmente } \\
\text { atraentes (1) } \\
\text { is Materia } \\
\text { comunicação } \\
\text { do espaço } \\
\text { que utilizo } \\
\text { são } \\
\text { visualmente } \\
\text { atraentes (2) }\end{array}$ & . & 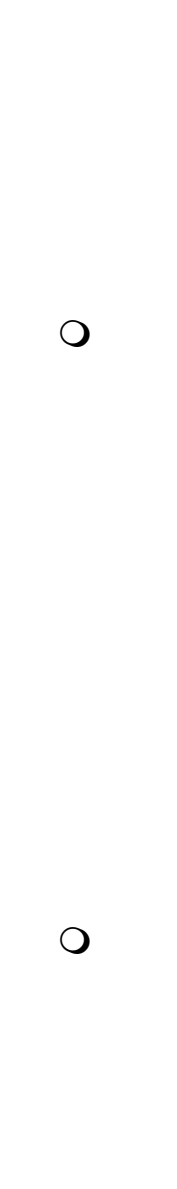 & 0 & 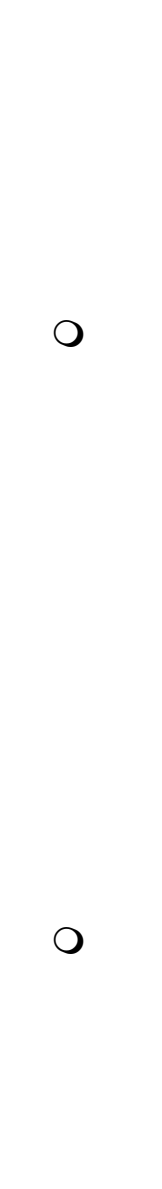 & 0 \\
\hline
\end{tabular}


10 Quanto à solução de problemas...

\begin{tabular}{|c|c|c|c|c|c|}
\hline & $\begin{array}{l}\text { Concordo } \\
\text { Totalmente } \\
\text { (1) }\end{array}$ & $\begin{array}{c}\text { Concordo } \\
\text { em Parte } \\
\text { (2) }\end{array}$ & $\begin{array}{c}\text { Não } \\
\text { Concordo } \\
\text { Nem } \\
\text { Discordo } \\
\text { (3) }\end{array}$ & $\begin{array}{c}\text { Discordo } \\
\text { em Parte } \\
\text { (4) }\end{array}$ & $\begin{array}{c}\text { Discordo } \\
\text { Totalmente } \\
\text { (5) }\end{array}$ \\
\hline $\begin{array}{l}\text { Excele } \\
\text { ntes } \\
\text { espaços } \\
\text { mostrarão } \\
\text { um } \\
\text { interesse } \\
\text { sincero em } \\
\text { resolver } \\
\text { problemas } \\
\text { de clientes } \\
\text { (1) } \\
\text { Quand } \\
\text { um tenho } \\
\text { um } \\
\text { problema, o } \\
\text { espaço que } \\
\text { utilizo } \\
\text { mostra um } \\
\text { interesse } \\
\text { sincero em } \\
\text { resolvê-lo } \\
\text { (2) }\end{array}$ & 0 & 0 & 0 & $\mathrm{O}$ & 0 \\
\hline
\end{tabular}


11 Quanto à vestimenta dos funcionários...

\begin{tabular}{|c|c|c|c|c|c|}
\hline & $\begin{array}{l}\text { Concordo } \\
\text { Totalmente } \\
\text { (1) }\end{array}$ & $\begin{array}{c}\text { Concordo } \\
\text { em Parte } \\
\text { (2) }\end{array}$ & $\begin{array}{c}\text { Não } \\
\text { Concordo } \\
\text { Nem } \\
\text { Discordo } \\
\text { (3) }\end{array}$ & $\begin{array}{c}\text { Discordo } \\
\text { em Parte } \\
\text { (4) }\end{array}$ & $\begin{array}{l}\text { Discordo } \\
\text { Totalmente } \\
\text { (5) }\end{array}$ \\
\hline $\begin{array}{l}\text { Os } \\
\text { funcionários } \\
\text { de espaços } \\
\text { excelentes } \\
\text { se vestirão } \\
\text { com } \\
\text { aparência } \\
\text { profissional } \\
\text { (1) } \\
\text { funcionários } \\
\text { do espaço } \\
\text { que utilizo } \\
\text { se vestem } \\
\text { com } \\
\text { aparência } \\
\text { profissional } \\
\text { (2) }\end{array}$ & 0 & O & O & O & $\mathrm{O}$ \\
\hline
\end{tabular}


12 Quanto ao registro de recados...

\begin{tabular}{|c|c|c|c|c|c|}
\hline & $\begin{array}{l}\text { Concordo } \\
\text { Totalmente } \\
\text { (1) }\end{array}$ & $\begin{array}{c}\text { Concordo } \\
\text { em Parte } \\
\text { (2) }\end{array}$ & $\begin{array}{c}\text { Não } \\
\text { Concordo } \\
\text { Nem } \\
\text { Discordo } \\
\text { (3) }\end{array}$ & $\begin{array}{c}\text { Discordo } \\
\text { em Parte } \\
(4)\end{array}$ & $\begin{array}{c}\text { Discordo } \\
\text { Totalmente } \\
\text { (5) }\end{array}$ \\
\hline \begin{tabular}{l} 
Funcio \\
nários de \\
excelentes \\
espaços \\
registrarão \\
sem erros os \\
recados, \\
cadastros e \\
as reservas \\
de salas \\
para os \\
clientes (1) \\
\multicolumn{1}{c}{ Funcio } \\
nários do \\
espaço que \\
utilizo \\
registram \\
meus \\
recados, \\
cadastros e \\
reservas de \\
salas, sem \\
erros (2)
\end{tabular} & 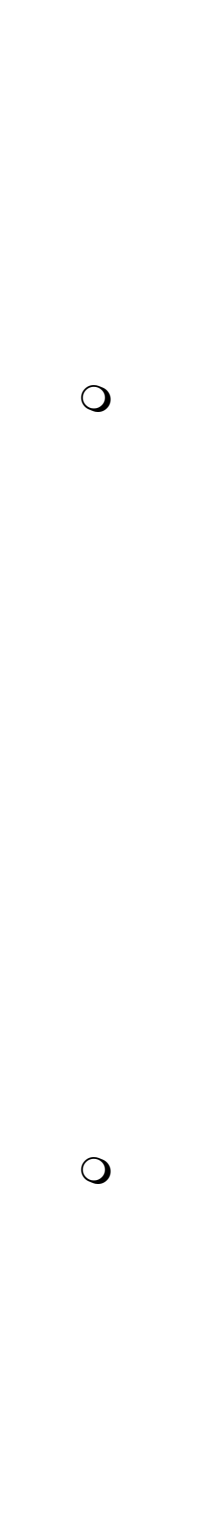 & 0 & 0 & 0 & 0 \\
\hline
\end{tabular}


13 Quanto a obtenção de informações...

\begin{tabular}{|c|c|c|c|c|c|}
\hline & $\begin{array}{l}\text { Concordo } \\
\text { Totalmente } \\
\text { (1) }\end{array}$ & $\begin{array}{c}\text { Concordo } \\
\text { em Parte } \\
\text { (2) }\end{array}$ & $\begin{array}{c}\text { Não } \\
\text { Concordo } \\
\text { Nem } \\
\text { Discordo } \\
\text { (3) }\end{array}$ & $\begin{array}{c}\text { Discordo } \\
\text { em Parte } \\
\text { (4) }\end{array}$ & $\begin{array}{l}\text { Discordo } \\
\text { Totalmente } \\
\text { (5) }\end{array}$ \\
\hline $\begin{array}{l}\text { Funcion } \\
\text { ários de } \\
\text { espaços } \\
\text { excelentes } \\
\text { terão dar } \\
\text { conhecimento } \\
\text { necessário } \\
\text { para clientes } \\
\text { informações } \\
\text { aos do } \\
\text { (1) } \\
\text { ários } \quad \text { duncion } \\
\text { espaço que } \\
\text { utilizo têm o } \\
\text { conhecimento } \\
\text { necessário } \\
\text { para me dar } \\
\text { informações } \\
\text { (2) }\end{array}$ & 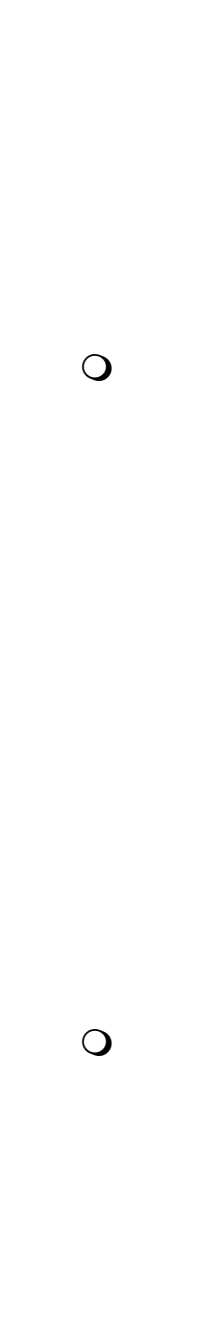 & O & 0 & ○ & 0 \\
\hline
\end{tabular}


14 Quanto ao comportamento dos funcionários...

\begin{tabular}{|c|c|c|c|c|c|}
\hline & $\begin{array}{l}\text { Concordo } \\
\text { Totalmente } \\
\text { (1) }\end{array}$ & $\begin{array}{c}\text { Concordo } \\
\text { em Parte } \\
\text { (2) }\end{array}$ & $\begin{array}{c}\text { Não } \\
\text { Concordo } \\
\text { Nem } \\
\text { Discordo } \\
\text { (3) }\end{array}$ & $\begin{array}{c}\text { Discordo } \\
\text { em Parte } \\
\text { (4) }\end{array}$ & $\begin{array}{l}\text { Discordo } \\
\text { Totalmente } \\
\text { (5) }\end{array}$ \\
\hline $\begin{array}{l}\text { O } \\
\text { comportamento } \\
\text { dos } \\
\text { funcionários de } \\
\text { espaços } \\
\text { excelentes } \\
\text { inspirará a } \\
\text { confiança dos } \\
\text { clientes (1) } \\
\text { O } \\
\text { comportamento } \\
\text { dos } \\
\text { funcionários do } \\
\text { espaço que } \\
\text { utilizo inspira a } \\
\text { minha } \\
\text { confiança (2) }\end{array}$ & 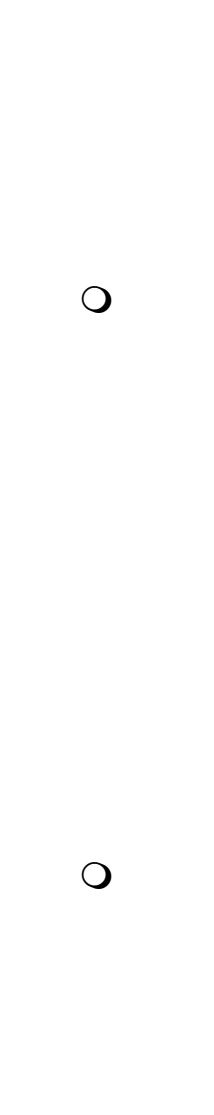 & 0 & $\mathrm{O}$ & 0 & 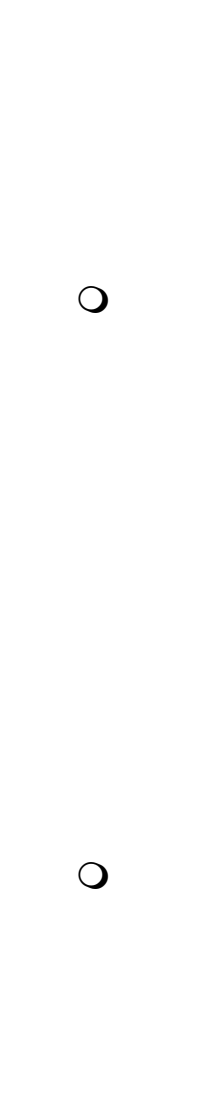 \\
\hline
\end{tabular}


15 Quanto à atenção prestada...

\begin{tabular}{|c|c|c|c|c|c|}
\hline & $\begin{array}{l}\text { Concordo } \\
\text { Totalmente } \\
\text { (1) }\end{array}$ & $\begin{array}{c}\text { Concordo } \\
\text { em Parte } \\
\text { (2) }\end{array}$ & $\begin{array}{c}\text { Não } \\
\text { Concordo } \\
\text { Nem } \\
\text { Discordo } \\
\text { (3) }\end{array}$ & $\begin{array}{c}\text { Discordo } \\
\text { em Parte } \\
\text { (4) }\end{array}$ & $\begin{array}{l}\text { Discordo } \\
\text { Totalmente } \\
\text { (5) }\end{array}$ \\
\hline $\begin{array}{l}\text { Os } \\
\text { funcionários } \\
\text { de espaços } \\
\text { excelentes } \\
\text { serão } \\
\text { sempre } \\
\text { atenciosos } \\
\text { com os } \\
\text { clientes (1) } \\
\text { Os } \\
\text { funcionários } \\
\text { do espaço } \\
\text { que utilizo } \\
\text { são sempre } \\
\text { atenciosos } \\
\text { comigo (2) }\end{array}$ & 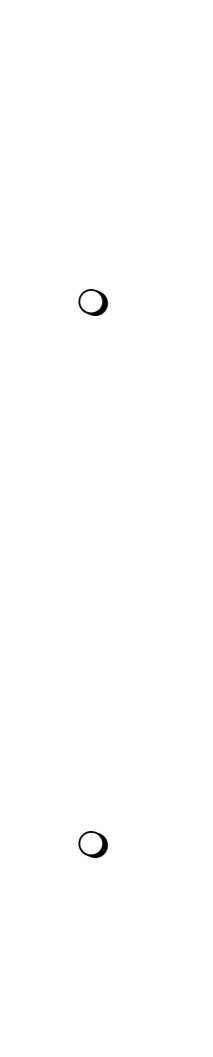 & 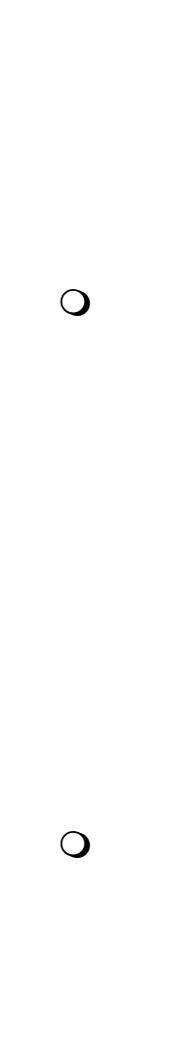 & 0 & 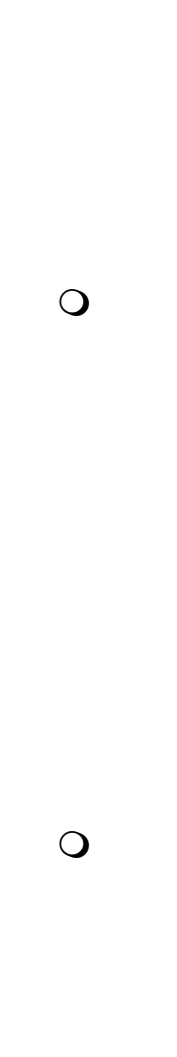 & 0 \\
\hline
\end{tabular}


16 Quanto ao entendimento de necessidades...

\begin{tabular}{|c|c|c|c|c|c|}
\hline & $\begin{array}{l}\text { Concordo } \\
\text { Totalmente } \\
\text { (1) }\end{array}$ & $\begin{array}{c}\text { Concordo } \\
\text { em Parte } \\
\text { (2) }\end{array}$ & $\begin{array}{c}\text { Não } \\
\text { Concordo } \\
\text { Nem } \\
\text { Discordo } \\
\text { (3) }\end{array}$ & $\begin{array}{c}\text { Discordo } \\
\text { em Parte } \\
\text { (4) }\end{array}$ & $\begin{array}{c}\text { Discordo } \\
\text { Totalmente } \\
\text { (5) }\end{array}$ \\
\hline $\begin{array}{l}\text { Os } \\
\text { funcionários } \\
\text { de espaços } \\
\text { excelentes } \\
\text { entenderão } \\
\text { as } \\
\text { necessidades } \\
\text { específicas } \\
\text { dos clientes } \\
\text { (1) } \\
\text { (1) Os } \\
\text { funcionários } \\
\text { do espaço } \\
\text { que utilizo } \\
\text { entendem as } \\
\text { necessidades } \\
\text { específicas } \\
\text { dos clientes } \\
\text { (2) }\end{array}$ & 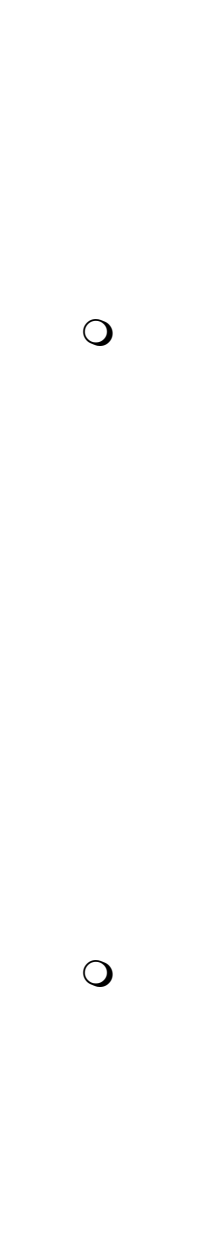 & O & 0 & 0 & 0 \\
\hline
\end{tabular}


17 Quanto à disposição em ajudar...

\begin{tabular}{|c|c|c|c|c|c|}
\hline & $\begin{array}{l}\text { Concordo } \\
\text { Totalmente } \\
\text { (1) }\end{array}$ & $\begin{array}{c}\text { Concordo } \\
\text { em Parte } \\
\text { (2) }\end{array}$ & $\begin{array}{c}\text { Não } \\
\text { Concordo } \\
\text { Nem } \\
\text { Discordo } \\
(3)\end{array}$ & $\begin{array}{c}\text { Discordo } \\
\text { em Parte } \\
\text { (4) }\end{array}$ & $\begin{array}{l}\text { Discordo } \\
\text { Totalmente } \\
\text { (5) }\end{array}$ \\
\hline $\begin{array}{l}\text { Os } \\
\text { funcionários } \\
\text { de espaços } \\
\text { excelentes } \\
\text { estarão } \\
\text { sempre } \\
\text { dispostos a } \\
\text { ajudar os } \\
\text { clientes (1) } \\
\text { Os } \\
\text { funcionários } \\
\text { do espaço } \\
\text { que utilizo } \\
\text { estão } \\
\text { sempre } \\
\text { dispostos a } \\
\text { me ajudar } \\
\text { (2) }\end{array}$ & . & . & 0 & 0 & 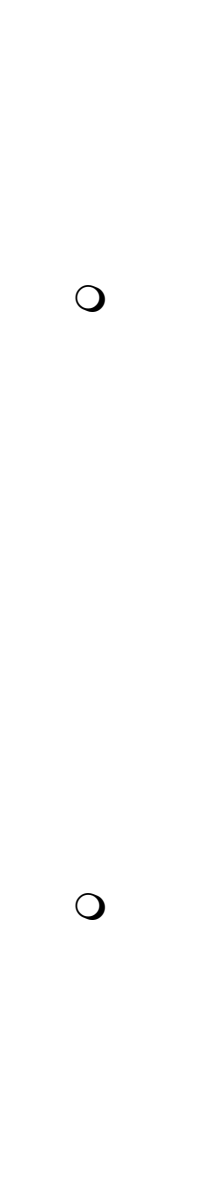 \\
\hline
\end{tabular}


18 Quanto aos horários de funcionamento...

\begin{tabular}{|c|c|c|c|c|c|}
\hline & $\begin{array}{l}\text { Concordo } \\
\text { Totalmente } \\
\text { (1) }\end{array}$ & $\begin{array}{c}\text { Concordo } \\
\text { em Parte } \\
\text { (2) }\end{array}$ & $\begin{array}{c}\text { Não } \\
\text { Concordo } \\
\text { Nem } \\
\text { Discordo } \\
\text { (3) }\end{array}$ & $\begin{array}{c}\text { Discordo } \\
\text { em Parte } \\
\text { (4) }\end{array}$ & $\begin{array}{l}\text { Discordo } \\
\text { Totalmente } \\
\text { (5) }\end{array}$ \\
\hline $\begin{array}{l}\text { Os } \\
\text { espaços } \\
\text { excelentes } \\
\text { terão horários } \\
\text { de } \\
\text { funcionamento } \\
\text { convenientes } \\
\text { para todos os } \\
\text { clientes (1) } \\
\text { O } \\
\text { espaço que } \\
\text { utilizo tem } \\
\text { horários de } \\
\text { funcionamento } \\
\text { convenientes } \\
\text { para todos os } \\
\text { clientes (2) }\end{array}$ & 更 & 0 & 0 & 0 & 0 \\
\hline
\end{tabular}


19 Quanto à pontualidade...

\begin{tabular}{|c|c|c|c|c|c|}
\hline & $\begin{array}{l}\text { Concordo } \\
\text { Totalmente } \\
\text { (1) }\end{array}$ & $\begin{array}{c}\text { Concordo } \\
\text { em Parte } \\
\text { (2) }\end{array}$ & $\begin{array}{l}\text { Não } \\
\text { Concordo } \\
\text { Nem } \\
\text { Discordo } \\
\text { (3) }\end{array}$ & $\begin{array}{c}\text { Discordo } \\
\text { em Parte } \\
\text { (4) }\end{array}$ & $\begin{array}{c}\text { Discordo } \\
\text { Totalmente } \\
\text { (5) }\end{array}$ \\
\hline \begin{tabular}{l}
\multicolumn{2}{c}{ Excelentes } \\
espaços \\
prestarão os \\
serviços com \\
pontualidade (ex: \\
reservas de sala, \\
entrega de \\
correspondências, \\
etc.) (1)
\end{tabular} & 0 & 0 & 0 & 0 & 0 \\
\hline $\begin{array}{l}\text { O espaço } \\
\text { que utilizo presta } \\
\text { os serviços com } \\
\text { pontualidade (2) }\end{array}$ & 0 & 0 & 0 & 0 & 0 \\
\hline
\end{tabular}


20 Quanto à personalização do atendimento...

\begin{tabular}{|c|c|c|c|c|c|}
\hline & $\begin{array}{l}\text { Concordo } \\
\text { Totalmente } \\
\text { (1) }\end{array}$ & $\begin{array}{c}\text { Concordo } \\
\text { em Parte } \\
\text { (2) }\end{array}$ & $\begin{array}{c}\text { Não } \\
\text { Concordo } \\
\text { Nem } \\
\text { Discordo } \\
\text { (3) }\end{array}$ & $\begin{array}{c}\text { Discordo } \\
\text { em Parte } \\
\text { (4) }\end{array}$ & $\begin{array}{l}\text { Discordo } \\
\text { Totalmente } \\
\text { (5) }\end{array}$ \\
\hline $\begin{array}{l}\qquad \text { Em } \\
\text { espaços } \\
\text { excelentes, } \\
\text { haverá } \\
\text { atendimento } \\
\text { personalizado } \\
\text { a cada cliente } \\
\text { (1) }\end{array}$ & 0 & 0 & 0 & 0 & 0 \\
\hline $\begin{array}{l}\quad \text { O } \\
\text { espaço que } \\
\text { utilizo } \\
\text { personaliza o } \\
\text { atendimento } \\
\text { a cada cliente } \\
\text { (2) }\end{array}$ & 0 & 0 & 0 & 0 & 0 \\
\hline
\end{tabular}


21 Qual sua idade?

O $15-25$ anos (9)

O 26 - 35 anos (10)

O 36-45 anos (11)

O 46-55 anos (12)

O 56-65 anos (13)

O 66 anos ou mais (14)

22 Sexo:

O Masculino (1)

O Feminino (2)

O Outros (3)

23 Sua área de atuação:

a Consultoria (1)

ㄱ Publicidade (2)

a Design (3)

- Marketing (4)

口 Internet (5)

- Startups (6)

- Advocacia/Jurídico (7)

- Negócios Sociais (8)

口 Vendas (9)

口 Jornalismo (10)

- Educação (11)

a Artes (13)

- Terceiro Setor (14)

a Contabilidade (15)

a Moda (16)

口 Outros (17)

Muito obrigada pela sua contribuição para essa pesquisa! 